\title{
Update The Monetary And Financial Policies Transparency Code
}




\section{INTERNATIONAL MONETARY FUND}

\section{IMF POLICY PAPER}

\section{STAFF PROPOSAL TO UPDATE THE MONETARY AND FINANCIAL POLICIES TRANSPARENCY CODE}

IMF staff regularly produces papers proposing new IMF policies, exploring options for reform, or reviewing existing IMF policies and operations. The following documents have been released and are included in this package:

- A Press Release summarizing the views of the Executive Board as expressed during its April 29, 2019 consideration of the staff report.

- The Staff Report, prepared by IMF staff and completed on April 1, 2019 for the Executive Board's consideration on April 29, 2019.

The IMF's transparency policy allows for the deletion of market-sensitive information and premature disclosure of the authorities' policy intentions in published staff reports and other documents.

Electronic copies of IMF Policy Papers

are available to the public from

http://www.imf.org/external/pp/ppindex.aspx

\section{International Monetary Fund Washington, D.C.}


Press Release No. 19/163

FOR IMMEDIATE RELEASE

May 13, 2019
International Monetary Fund

$70019^{\text {th }}$ Street, NW

Washington, D.C. 20431 USA

\section{IMF Executive Board Reviews Proposal to Update the Monetary and Financial Policies Transparency Code}

On April 29, 2019, the Executive Board of the International Monetary Fund (IMF) discussed a paper proposing an update of the Monetary and Financial Policies Transparency Code (MFPT), by means of replacing it by a new Central Bank Transparency Code (CBT). The update is in line with the recommendations of the 2017 Joint Review of the Standards and Codes Initiative, indicating the need for risk-based assessments to support policy effectiveness and address macroeconomic risks.

The paper outlines how the CBT will remove the overlap in the MFPT with transparency elements of financial policies covered by other international standards and expand the central bank transparency standard to a broader set of activities undertaken by many central banks since the Global Financial Crisis, including changes in monetary policy practices.

The paper emphasizes the applicability of the CBT to all IMF members, including lessdeveloped economies. The modular, risk-based, and proportional setup would allow taking into account country-specific circumstances. This would enable the CBT to serve as a tailored diagnostic tool in IMF capacity development. CBT assessments would help support IMF surveillance, such as Article IV reviews and Financial Sector Assessment Programs, and would be useful in an IMF Program context, as was the case for the MFPT.

\section{Executive Board Assessment ${ }^{1}$}

Executive Directors welcomed the opportunity to consider the staff proposal to update the Monetary and Financial Policies Transparency (MFPT) Code. They noted that the development of financial sector standards by international standard setting bodies and important developments in central bank mandates and activities since the Global Financial Crisis (GFC) contributed to the disuse of the MFPT. Against this background, Directors

\footnotetext{
${ }^{1}$ An explanation of any qualifiers used in the summing up can be found here: http://www.imf.org/external/np/ $\mathrm{sec} / \mathrm{misc} /$ qualifiers.htm.

Washington, D.C. 20431 • Telephone 202-623-7100 • Fax 202-623-6772 • www.imf.org 
endorsed the proposal to replace the MFPT with a new Central Bank Transparency (CBT) Code. They generally viewed the proposed CBT as an appropriate framework to remove the overlap on financial policies covered by other FSB standards, and expand the transparency standards to a broader set of activities and practices undertaken by many central banks since the GFC. The CBT would also reorient transparency standards to facilitate risk-based assessments to support policy effectiveness and address macroeconomic risks, in line with the recommendations of the 2017 Joint Review of the Standards and Codes Initiative.

Directors welcomed the proposal's emphasis on ensuring that the CBT is relevant for all member countries, including less-developed and smaller economies, recognizing that central banks operate under a diverse set of circumstances and environments. In this regard, they agreed with the proposed modular approach of the CBT and considered that flexibility would help facilitate a risk-based and proportional application while taking into account country-specific circumstances and needs. Directors broadly concurred that the proposed CBT can serve as a diagnostic tool in capacity development, and help central banks map their transparency frameworks and make informed choices on their transparency arrangements. Many Directors also considered that CBT assessments could help support Fund surveillance. Some Directors underscored the importance of clarifying the voluntary nature of the CBT.

Directors welcomed that the CBT will take as given the mandates, policies, and governance arrangements of central banks. They broadly agreed that the CBT would tie into existing governance work within the Fund and noted that the CBT will not provide a central bank governance framework, nor is it a means to assess or pass judgement on the governance of central banks.

Directors noted that central banks face trade-offs between transparency and the legitimate need for confidentiality. In this regard, they considered that the CBT code should strike the appropriate balance between these needs and preserve flexibility, particularly in the context of market sensitive information and financial stability and policy effectiveness objectives.

Directors supported the staff proposal to convene an international Advisory Group to provide guidance to staff in the elaboration of the new code. Directors noted the importance of selecting the members of the Advisory Group from diverse backgrounds and regions to ensure a broad representation of views and experiences.

Directors emphasized the need for broader consultation on the proposed CBT in due course, including with monetary authorities, other international institutions, and the Executive Board. Directors also asked for more regular updates to the Executive Board as the CBT is developed. 


\section{INTERNATIONAL MONETARY FUND}

April 1, 2019

\section{STAFF PROPOSAL TO UPDATE THE MONETARY AND FINANCIAL POLICIES TRANSPARENCY CODE}

\section{EXECUTIVE SUMMARY}

The paper responds to a request made by the Executive Board at the time of the 2017 Review of the Standards and Codes Initiative (RSCI) for a revision and update of the 1999 Monetary and Financial Policies Transparency Code (MFPT). Directors asked staff that the new code remove the overlap on financial policies covered by other standards, expand the transparency standards to broader set of activities undertaken by many central banks since the Global Financial Crisis, and reorient the transparency standards to facilitate risk-based assessments to support policy effectiveness and address macroeconomic risks.

This paper presents a staff proposal to update the MFPT. The proposal narrows the perimeter of the code to central banks only but broadens the areas on which transparency would be assessed. Concretely, staff proposes the development of a new Central Bank Transparency code (CBT) comprising five "Transparency Pillars" covering governance, policies, operations, outcomes, and official relations. The proposed modular approach of the CBT will also facilitate a risk-based and proportional application that takes into account country-specific circumstances.

The CBT could be "plugged" in Fund capacity building activities (technical assistance and Financial Sector Stability Reviews), surveillance (Article IV consultations and FSAPs), Use of Fund Resources (UFR), and in the Fund's Good Governance framework. The CBT could also be used by central banks themselves to map their transparency frameworks and make informed choices on their transparency arrangements.

Staff is seeking Board endorsement of the proposed approach to prepare the CBT in FY2020 and to consult with an external advisory group prior to further Board discussion. 
Approved By

Tobias Adrian
Prepared by Ghiath Shabsigh and Ashraf Khan (both MCM), with input from Marcela Matamoros (MCM Consultant) and in consultation with other departments. Production assistance was provided by Danica Owczar and Andre Vasquez.

\section{CONTENTS}

Glossary

INTRODUCTION $\underline{4}$

KEY CONSIDERATIONS FOR THE UPDATE

TRANSPARENCY IN CENTRAL BANKS

THE PROPOSED CENTRAL BANK TRANSPARENCY FRAMEWORK $\underline{11}$

THE CENTRAL BANK TRANSPARENCY FRAMEWORK: CASE STUDIES $\underline{14}$

SUMMARY AND NEXT STEPS $\underline{17}$

ISSUES FOR DISCUSSION $\underline{17}$

References $\underline{18}$

BOX

1. Central Bank Accountability Following the GFC

\section{FIGURES}

1. MFPT Assessments, 1999-2017 $\underline{5}$

2. Coverage of Transparency of Financial Policies in FSB Standards and Codes ___

3. Central Banks' Objectives and Instruments

4. Policy, Autonomy, Transparency, and Accountability_____ $\underline{9}$

5. Central Bank Transparency: Five-Pillar Framework ___ $\frac{13}{15}$

6. Aggregate Transparency Results of Sample Central Banks___ 15

\section{TABLE}

1. CBT Case Studies: Summary Results for the Whole Sample

\section{ANNEXES}

I. Central Bank Transparency Framework 20

II. Central Bank Transparency Framework: Case Studies $\underline{30}$

III. Central Bank Transparency Code and Transparency of Financial Policies 40 


\section{Glossary}

$\begin{array}{ll}\text { AML/CFT } & \text { Anti-Money Laundering and Countering the Financing } \\ \text { of Terrorism } \\ \text { BCBS } & \text { Basel Committee on Banking Supervision } \\ \text { BCP } & \text { Basel Core Principles } \\ \text { CBLD } & \text { Central Bank Legislation Database } \\ \text { CBT } & \text { Central Bank Transparency } \\ \text { CPMI-IOSCO } & \text { Committee on Payments and Market Infrastructures- } \\ & \text { IOsCO } \\ \text { ECB } & \text { European Central Bank } \\ \text { EMs } & \text { Emerging Markets } \\ \text { FIU } & \text { Financial Intelligence Unit } \\ \text { FMI } & \text { Financial Market Infrastructure } \\ \text { FSAP } & \text { Financial Sector Assessment Program } \\ \text { FSSR } & \text { Financial Sector Stability Review } \\ \text { GFC } & \text { Global Financial Crisis } \\ \text { IAIS } & \text { International Association of Insurance Supervisors } \\ \text { IMF } & \text { International Monetary Fund } \\ \text { IOSCO } & \text { International Organization of Securities Commissions } \\ \text { LICS } & \text { Low-Income Countries } \\ \text { MFPT } & \text { IMF Code of Good Practices on Transparency in } \\ \text { QE } & \text { Monetary and Financial Policies } \\ \text { RSCI } & \text { Quantitative Easing } \\ \text { S\&C } & \text { Review of the Standards and Codes Initiative } \\ \text { UFR } & \text { Standards and Codes } \\ \text { UMP } & \text { Use of Fund Resources } \\ & \text { Unconventional Monetary Policies } \\ & \end{array}$




\section{INTRODUCTION}

\section{The 1999 IMF Code of Good Practices on Transparency in Monetary and Financial} Policies (MFPT) provides guidance for policy transparency. ${ }^{1}$ The MFPT (one of the Key Standards developed by the IMF) ${ }^{2}$ identifies desirable transparency practices for central banks in their conduct of monetary policy, and for central banks and other financial agencies in their conduct of financial policies. It defines transparency as an environment in which the objectives of policy; its legal, institutional, and economic framework; policy decisions and their rational; data and information related to monetary and financial policies; and, the terms of agencies' accountability are provided to the public on an understandable, accessible and timely basis.

\section{The MFPT focuses on several aspects of monetary policy and financial policy decisions.}

Concretely, the transparency practices covered in the MFPT include:

- the clarity of roles, responsibilities and objectives of central banks and financial agencies;

- the processes for formulating and reporting decisions (monetary policy decisions by the central bank and financial policies by financial agencies);

- the public availability of information on monetary and financial policies; and

- accountability and assurances of integrity by the central bank and financial agencies.

3. A revision of the MFPT has been under consideration for several years. The 2011 Review of the Standards and Codes $(\mathrm{S} \& \mathrm{C})$ Initiative $(\mathrm{RSCl})^{3}$ noted that the Fund will revise the MFPT to remove the overlap on financial policies currently covered by other standards and update the monetary policy transparency standards in light of the Global Financial Crisis (GFC). The revisions were expected to be completed by 2012, but as explained in the $2017 \mathrm{RSCl}^{,}$they were put on hold because monetary policy practices in key central banks continued to evolve. The $2017 \mathrm{RSCl}$ recommended maintaining the goal of producing an update to the MFPT and asked staff to present to the Board concrete proposals for a new code and the way forward in FY2019.

4. The MFPT has gradually fallen into disuse. Very few assessments have taken place over the past 10 years (Figure 1). Several factors may have contributed to this outcome, including (as noted by the $2017 \mathrm{RSCl}$ ): the development of financial-sector standards by international standardsetting bodies, changes in monetary policy practices in the aftermath of the GFC (especially

\footnotetext{
${ }^{1}$ IMF, 1999, Code of Good Practices on Transparency in Monetary and Financial Policies: Declaration of Principles. Washington: International Monetary Fund. The Code was endorsed by the Interim Committee of the IMF Board of Governors in its September 26, 1999 Communiqué, which urged all member countries to implement it.

${ }^{2}$ In addition to the MFPT the list of Standard and Codes developed by the IMF are: (1) Fiscal Transparency Code, and (2) the General Data Dissemination Standard (SDDS).

3 IMF, 2011, The 2011 Joint Review of the Standards and Codes Initiative, February 16, 2011.

4 IMF, 2017, The 2017 Joint Review of the Standards and Codes Initiative, August 3, 2017.
} 
Unconventional Monetary Policies (UMP). Interest on the code may have been dampened also by the expectation of the overhaul of the code as called for in the $2011 \mathrm{RSCl}$.

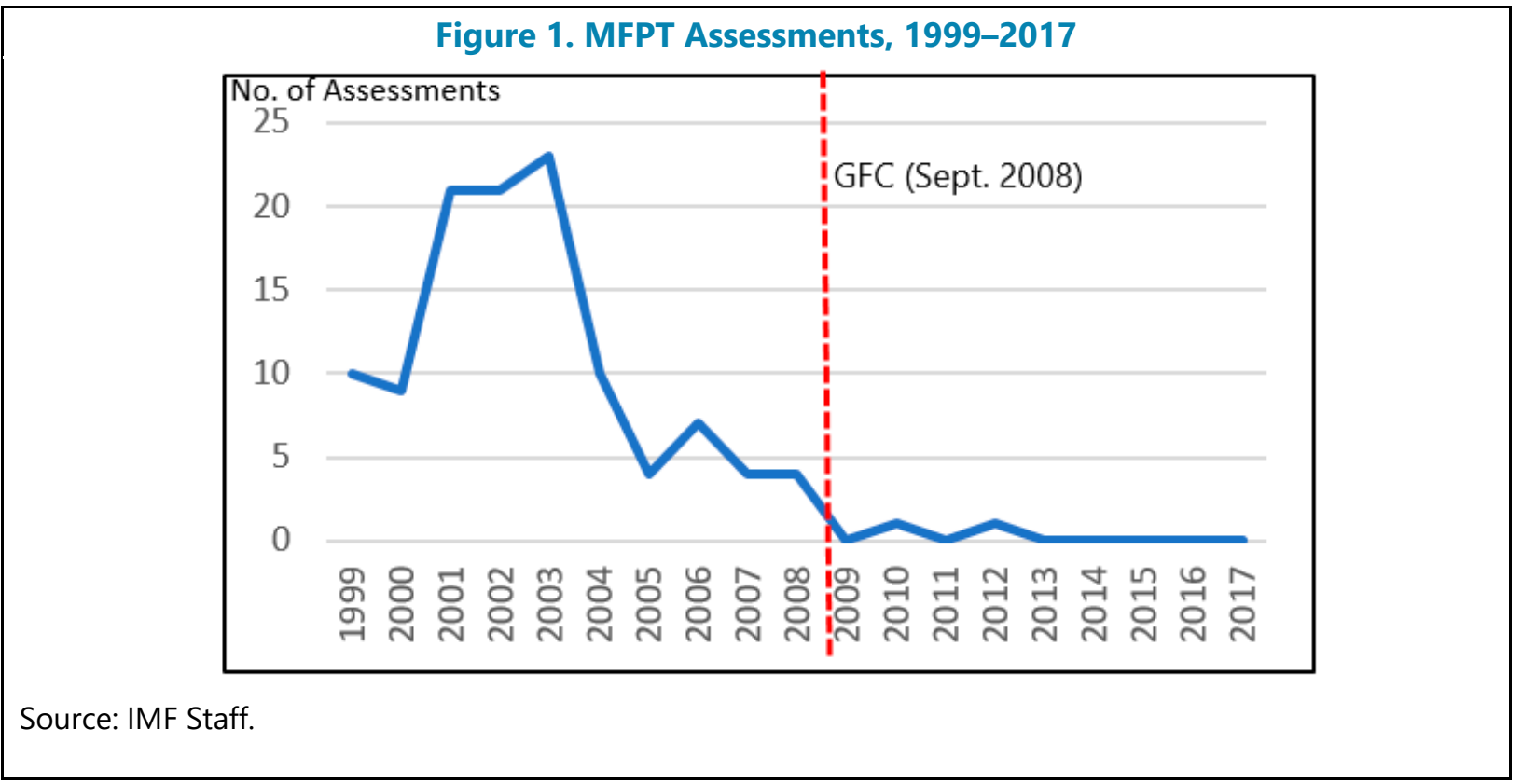

5. This paper presents a staff proposal to update the MFPT. The next section discusses the key factors that are considered in the assessment of the scope of the MFPT update. The subsequent section highlights the need to enhance the transparency of central banks in light of their broader and more complex mandates following the GFC. Building on this, the following section proposes a new central bank transparency framework. The final section presents the results of the extensive case studies of central bank transparency practices that are used to refine the proposed framework.

\section{KEY CONSIDERATIONS FOR THE UPDATE}

6. Staff has assessed carefully the scope and practicality of updating the 1999 MFPT. Key factors considered in the assessment include:

- The importance of maintaining the quality and increasing the relevance of the MFPT. The MFPT is one of three transparency standards set by the Fund but is in need of update to ensure broad applicability to the membership, including low-income countries (LICs), reflect lessons learned in other policy areas, and promote better alignment with surveillance and capacity development.

- The advances in the development of international standards for financial policies since 1999. The comprehensiveness of the current set of international standards for financial policies makes redundant to propose separate transparency principles for financial policies in a revised MFPT (Figure 2). Annex III provides more detailed overview of transparency elements in standards and principles for financial policies. 
- The monetary policy practices of many central banks since the GFC. These recent practices have altered many of the norms that underpinned the transparency principles related to monetary policy in the MFPT. Central banks have expanded their balance sheets, using UMP to support price stability objectives, and have also taken financial stability considerations into account for their monetary policy actions and decisions. The MFPT, with its narrow focus on conventional monetary policy activities, does not capture well the post GFC monetary policy environment.

- The broadening of mandates, functions, and powers-both de jure and de facto-of central banks since the GFC. In addition to UMP, many central banks (whether in countries affected by the GFC, or not) have seen their financial stability functions broadened to encompass macroprudential oversight, crisis management, and resolution. Some central banks have also assumed non-traditional objectives (e.g., financial integrity ${ }^{5}$ and consumer protection). Many of these functions and activities of central banks were not contemplated in the MFPT.

- The 2017 RSCI recommendation that the Fund's transparency S\&C be geared at facilitating implementation of policy objectives, to support policy effectiveness and address macroeconomic risks, instead of focusing mostly on disclosure of operational processes.

- The Fund's approach to governance issues. In April 2018, the Board approved a framework for enhanced Fund engagement on governance and corruption. ${ }^{6}$ The framework aims at assessing governance vulnerabilities and their macroeconomic impact in the context of Article IV assessments. This new framework includes a central bank component examining several governance issues, including, most importantly, transparency and accountability arrangements.

7. The factors listed above point to the need for a comprehensive overhaul of the MFPT focused on the central bank as an institution. Removing the financial policies from the MFPT would limit the scope of its transparency coverage to monetary policy. However, as discussed above, the post-GFC environment facing central banks calls for stronger and more comprehensive transparency covering the complex set of functions and relations that central banks are engaged in. Accordingly, staff proposes that the overhaul broadens the coverage of the code by expanding the activities of the central bank that it assesses and narrows the perimeter of the code by confining it to the central bank (i.e., an institutional or "entity-based" approach). This proposal would replace the MFPT by a Central Bank Transparency (CBT) code.

8. The proposed code would tie into existing governance work within the Fund. The CBT will be conceptually and operationally different from the ongoing Fund work on central bank governance in the post-GFC environment. The latter covers a broad spectrum of central bank governance-related issues, of which transparency is only one element. The CBT framework has

\footnotetext{
${ }^{5}$ See, for instance, IMF, 2019, Review of the Fund's Strategy on Anti-Money Laundering and Combating the Financing of Terrorism, Staff Report, February 2019. Washington: International Monetary Fund.

${ }^{6}$ IMF, 2018b, Review of 1997 Guidance Note on Governance-A Proposed Framework for Enhanced Fund Engagement. Washington: International Monetary Fund.
} 
benefited from the ongoing discussions on central bank governance but would focus on central bank transparency only, rather than central bank governance. The new code would not be geared towards assessing the adequacy of central bank mandates, autonomy, governance, policies, or operations. It would also not try to pass judgment on the choices that countries may have made regarding the institutional setup of their central bank. Rather, the proposed CBT will take as given the mandates, policies and governance arrangements of countries' central banks and evaluate the degree of transparency that underpin those choices.

Figure 2. Coverage of Transparency of Financial Policies in FSB Standards and Codes ${ }^{1}$

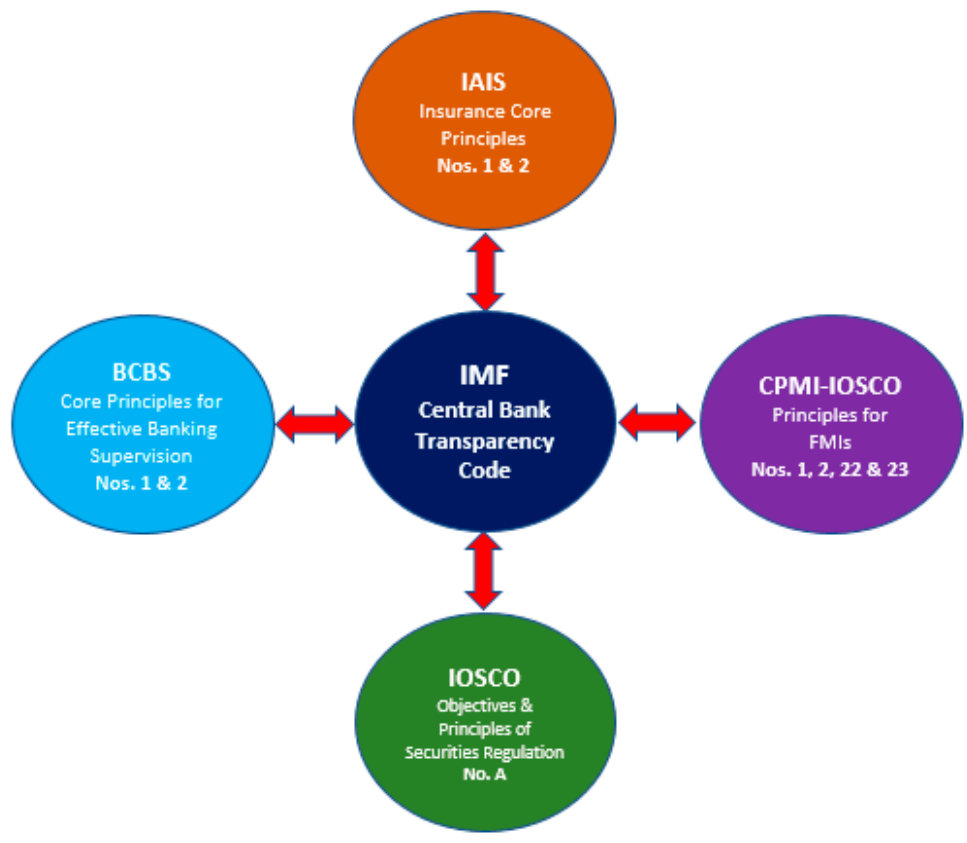

Source: IMF Staff.

${ }^{1}$ Note: The CBT would be applicable to all IMF members. 
9. The CBT will allow central banks to map their transparency frameworks. Using the CBT, central banks could assess their existing transparency frameworks and allow for more informed central bank choices on transparency and discussions between the central bank and its various stakeholders. It will also assist central banks in explaining that the absence of specific information (for instance, on specific micro prudential cases) does not necessary imply lacking transparency, nor that transparency should always be full and complete.

\section{TRANSPARENCY IN CENTRAL BANKS}

10. The broader and more complex mandates of central banks following the GFC has strengthened the case for enhanced central bank transparency. Prior to the GFC, accountability and transparency mechanisms for central banks were largely geared to strengthening a monetary policy-centric mandate and thus addressed issues such as the predictability of monetary policy, the anchoring of inflation expectations, and ways to strengthen the transmission mechanism. However, as noted, in the wake of the GFC, many central banks had to take actions that went beyond a narrow interpretation of their mandates. As a result, central banks saw their mandates broadened considerably, both de jure and de facto (Figure 3 presents a simple diagram of many possible central bank objectives and functions). These developments have increased the importance of enhanced transparency arrangements as a key element of making central banks accountable for their decisions and actions.

\section{Similarly, the need for central bank transparency for LICs is particularly relevant for} effective monetary policy. The $\mathrm{IMF}^{7}$ has highlighted the need for appropriate central bank transparency arrangements as one of the sound principles of monetary policy, allowing for proper public accountability of the central bank for fulfilling its objectives. In general, central bank transparency of lower- and middle-income countries remains behind transparency in emerging markets and advanced economies. ${ }^{8}$

\footnotetext{
7 IMF, 2015, Evolving Monetary Policy Frameworks in Low-Income Countries and Other Developing Countries. Washington: International Monetary Fund.

8 See also Dincer, N., B. Eichengreen. 2014, Central Bank Transparency and Independence: Updates and New Measures, International Journal of Central Banking, Vol. 38(3), pp. 189-253., and IMF, 2014, Macroeconomic Developments in Low-Income Developing Countries, IMF Policy Paper. Washington: International Monetary Fund.
} 
Figure 3. Central Banks' Objectives and Instruments

\begin{tabular}{|c|c|c|c|c|c|c|c|c|c|c|}
\hline \multirow{2}{*}{\multicolumn{2}{|c|}{$\begin{array}{ll}\text { Instruments } & \text { Policy objectives } \\
\end{array}$}} & \multirow{2}{*}{\begin{tabular}{l|l|} 
Price \\
Stability
\end{tabular}} & \multicolumn{4}{|c|}{ Financial Stability } & \multirow{2}{*}{$\begin{array}{l}\text { Payment } \\
\text { System }\end{array}$} & \multirow{2}{*}{$\begin{array}{l}\text { Financial } \\
\text { Integrity }\end{array}$} & \multirow{2}{*}{$\begin{array}{l}\text { Consumer } \\
\text { Protection }\end{array}$} & \multirow{2}{*}{$\begin{array}{l}\text { Growth \& } \\
\text { Employment }\end{array}$} \\
\hline & & & Macro & Micro & ELA & Resolution & & & & \\
\hline $\begin{array}{l}\text { Monetary, } \\
\text { Currency, and } \\
\text { Payments }\end{array}$ & $\begin{array}{l}\text { For example, OMO, FX } \\
\text { reserves management, FX } \\
\text { operations, cash currency, } \\
\text { payment instruments }\end{array}$ & & & & & & & & & \\
\hline $\begin{array}{l}\text { Macro } \\
\text { Prudential }\end{array}$ & $\begin{array}{l}\text { For instance, CCB, LTV, DSTI, } \\
\text { additional cap. requirements }\end{array}$ & & & & & & & & & \\
\hline $\begin{array}{l}\text { Micro } \\
\text { Prudential }\end{array}$ & $\begin{array}{l}\text { For instance, licensing, } \\
\text { capital, disclosure, and fit \& } \\
\text { proper requirements, stress } \\
\text { tests }\end{array}$ & & & & & & & & & \\
\hline $\begin{array}{l}\text { Crisis } \\
\text { Management }\end{array}$ & $\begin{array}{l}\text { For instance, ELA, recovery } \\
\text { and resolution planning }\end{array}$ & & & & & & & & & \\
\hline AML/CFT & $\begin{array}{l}\text { For instance, reporting } \\
\text { requirements, KYC/CDD }\end{array}$ & & & & & & & & & \\
\hline
\end{tabular}

Source: IMF Staff.

12. Central bank transparency is closely linked to the concepts of central bank autonomy and accountability. ${ }^{9}$ Central bank autonomy relates to the institution's ability to formulate and implement the policies under its mandate without undue influence (or the perception of influence) from the executive or legislative powers, financial institutions, or other external stakeholders. Autonomy is what enables a central bank to adjust its policies in the direction and size that it deems necessary to attain the objectives under its mandate (see Annexes I and II for an extensive discussion of the concept of central bank autonomy). However, central banks do not operate in a vacuum and should, within limits, be transparent about their operations and activities to enhance their credibility and effectiveness. This transparency is an integral component of the central bank's accountability vis-a-vis legislative and executive branches of government and the public. Modern central banks are expected to explain and justify their actions and give account of the decisions made in the execution of its responsibilities and the use of the resources that are entrusted to it. (Figure 4).

Figure 4. Policy, Autonomy, Transparency, and Accountability

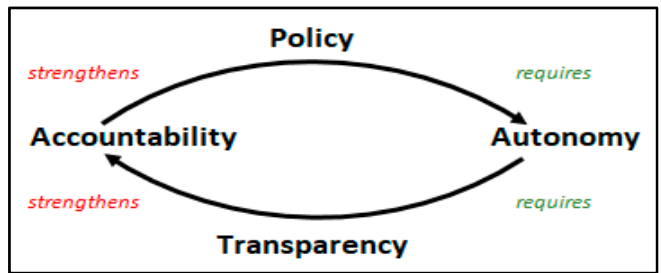

Source: IMF Staff.

\footnotetext{
${ }^{9}$ The terms "independence" and "autonomy" are often used interchangeably. "Independence" is predominantly used in central bank legal frameworks, though with some variations, and some countries combine both terms. For clarity's sake, and without indicating a specific preference, this paper will use the term "autonomy." See also Annex I, and Khan, A., 2017, Central Bank Legal Frameworks in the Aftermath of the Global Financial Crisis, IMF Working Paper 17/101. Washington: International Monetary Fund.
} 


\section{External and internal accountability arrangements ensure that the central bank can be} discharged for how it is trying to achieve its mandate. External accountability arrangements cover (a) how the central bank reports, explains, and justifies its decisions and actions; (b) to whom the central bank reports to; and (c) how the central bank ensures timely access to information (including its financial statements). Internal accountability arrangements include those related to internal audit and external audit procedures, as well as an ethical and anti-corruption framework for central bank staff and its board.

\section{Transparency contributes to shape central bank's accountability. Central bank}

transparency arrangements relate to the flow and accessibility of information from the central bank: the ease with which stakeholders can understand and interpret the central bank's actions which, in turn, would inform the judgment stakeholders make on the central bank's performance and broad compliance with its mandate. Transparency, therefore, is a tool within the central bank's broader governance and accountability framework, which includes other elements that are not relevant to this work (Box 1).

15. Central bank transparency should be weighed against confidentiality. Central bank transparency is a broad concept that covers transparency of the mandate; governance arrangements; degrees of autonomy; and, the policy areas, operations, and outcomes related to central bank decisions, as well as key external relations. The application of transparency in a central bank context, however, cannot be indiscriminate or excessive as there are many central bank activities where there are legitimate needs for confidentiality. As the MFPT noted: "Transparency is not an end in itself, nor is transparency a substitute for pursuing sound policies; rather, transparency and sound policies are better seen as complements." ${ }^{10}$

\footnotetext{
10 IMF, 1999, Code of Good Practices on Transparency in Monetary and Financial Policies: Declaration of Principles. Washington: International Monetary Fund. P. 7, para. 12.
} 


\section{Box 1. Central Bank Accountability Following the GFC}

As the GFC changed central bank mandates, accountability arrangements followed suit. Central banks actions and program motivated by financial stability considerations, in particular those related to emergency liquidity assistance (ELA) led to calls for the greater openness about the legal basis and tools and instruments used by central banks. These calls were particularly prominent in the U.S., the U.K., and several other European countries. In some countries, the adoption of UMP raised questions about the appropriateness of the policy and its transparency. More recently, other countries have questioned their central banks' involvement on topics such as climate change and financial sector ethics. Whether these questions are warranted or not, in either case they have often spurred enhanced central bank accountability.

Increased macroprudential oversight powers also affect central bank accountability arrangements. The central bank's role in macroprudential oversight was often not clearly defined prior to the crisis. Many countries have since clarified the institutional arrangements for macroprudential policy and the role of central banks within these arrangements. Nonetheless, this is an area that still often entails shared responsibilities with other institutions, such as the Ministry of Finance, and other financial supervisory and regulatory agencies funds introducing additional complexity when it comes to thinking about central bank transparency (see IMF, 2013, "Key Aspects of Macroprudential Policy," June 10, 2013. Washington: International Monetary Fund, and IMF, 2018a, The IMF's Annual Macroprudential Policy Survey, April 2018. Washington: International Monetary Fund).

Without indicating a policy preference, all these developments further spurred the discussion on central bank accountability.

\section{THE PROPOSED CENTRAL BANK TRANSPARENCY FRAMEWORK}

\section{The CBT framework proposed by staff to replace the MFPT:}

- maintains some key principles of the MFPT;

- adapts the code's coverage to reflect the post-GFC activities and practices of central banks;

- takes into account that central banks operate under a diverse set of circumstances and environments; 
- would allow assessments of transparency ${ }^{11}$ that are outcome-focused, modular, risk-based, and proportional; and

- would support policy conduct and communications by the central bank and contribute to enhance central bank accountability.

\section{Assessments based on the proposed CBT framework could help support Fund}

surveillance. When applied to a member country, the framework will help highlight the strengths and weaknesses of the central banks' transparency practices and their relative importance. The scope to undertake modular assessments of the components of the code would allow a prioritization of recommendations through a transparency action plan that could be monitored, depending on country-specific priorities, in the context of Article IV surveillance, Financial Sector Assessment Programs (FSAPs), and UFR-including Safeguards Assessments.

18. The CBT framework can serve as a diagnostic tool in capacity development. As the CBT framework is developed further and applied to member countries, it will provide key elements of central bank transparency regardless of the effects of the institutional framework and other countryspecific elements. This, in turn, would enable the delineation of benchmarks and allow graduated assessment of conformity of central banks' transparency practices, helping less-developed countries plan, implement, and monitor reform efforts. This could assist authorities to provide well-founded information on central bank transparency and communicate to relevant stakeholders accordingly.

\section{The proposed CBT framework would comprise five "Transparency Pillars," each} representing a different transparency module (Figure 5$):{ }^{12}$

- Pillar I. Transparency in governance, covering institutional issues. ${ }^{13}$

- Pillar II. Transparency in policies, focusing on the economics of the central bank decisions.

- Pillar III. Transparency in operations, highlighting how policy decisions are implemented.

- Pillar IV. Transparency in outcome, focusing on the outcome of central bank policies and other actions are reported to stakeholders.

\footnotetext{
${ }^{11}$ Note that the assessment would be transparency of the central bank only. In those cases where the central bank shares a function with one or more other agencies, transparency of those agencies would not be assessed by the CBT framework. Furthermore, insofar that the central bank is the micro-prudential (banking and/or insurance) supervisor, securities regulator, and/or Financial Market Infrastructures (FMI), the relevant international standards and codes will apply.

12 The framework was developed based on an extensive review of the relevant literature, legislation, and current central banks' transparency arrangements. It also draws on staff advice provided to central banks in recent years in the context of technical assistance and surveillance activities.

${ }^{13}$ These issues include "internal accountability" and relate to institutional arrangements, tools, and codes of conduct. This concept is different from the concept of external accountability of the central bank vis-à-vis its stakeholders.
} 
- Pillar V. Transparency in official relations, covering the central bank interaction with the government and other domestic agencies, and international relations and commitments.

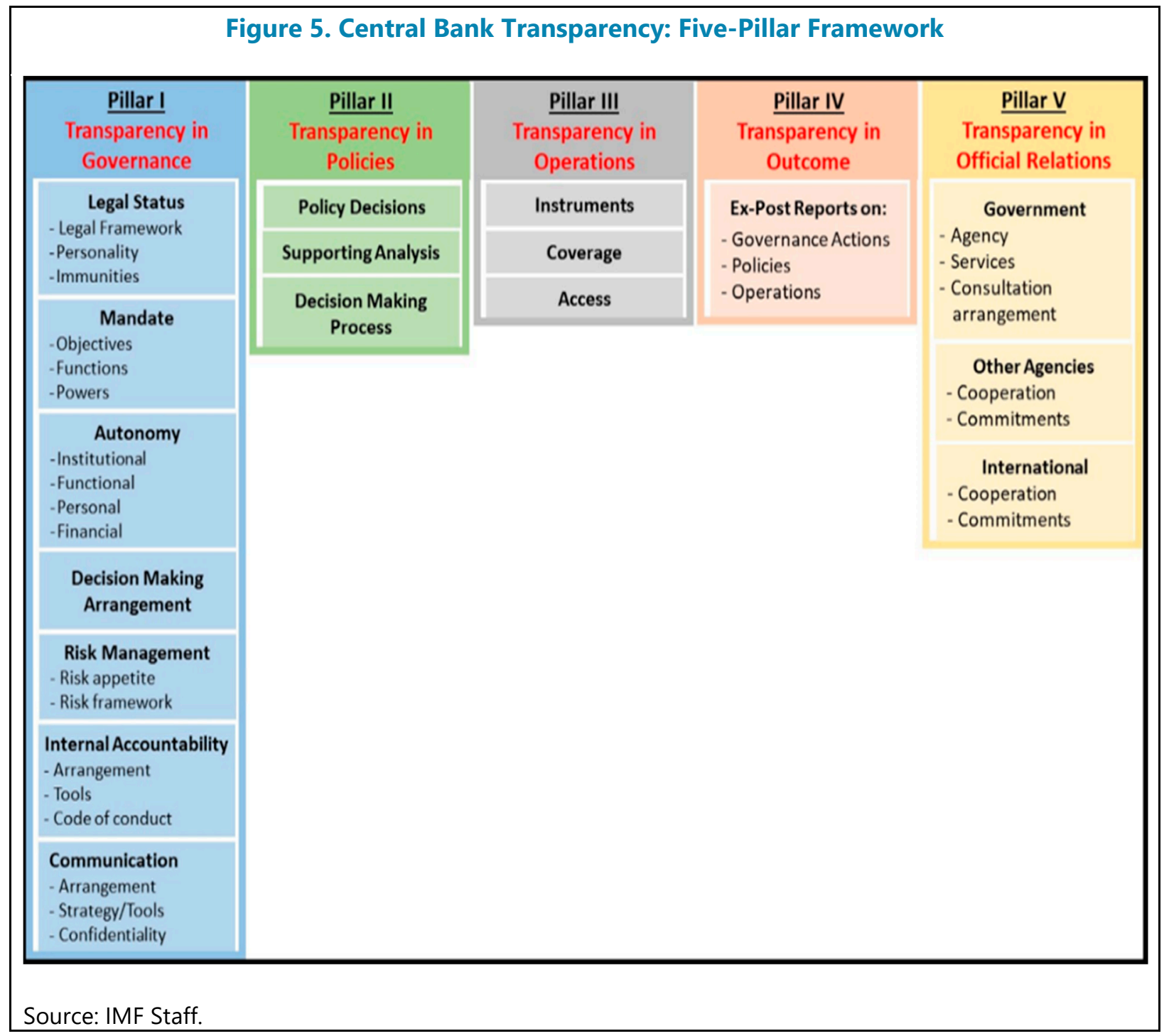




\section{THE CENTRAL BANK TRANSPARENCY FRAMEWORK: CASE STUDIES}

20. The proposed framework was refined by undertaking a rigorous and detailed analysis of central bank transparency practices in a group of central banks from 24-member countries and the European Central Bank (ECB). ${ }^{14}$ The sample of central banks was chosen to include Fund members from different geographical regions, income levels, and diverse central bank mandates. The application of the proposed CBT framework on the sample was used to detect emerging and best practice, assessing the robustness of the CBT framework in diverse economic and institutional environments, and documenting the transparency practices of the central banks in the sample

21. The exercise required undertaking a careful desk review of all available public information related to the five pillars of the proposed framework. The information reviewed included:

- Legal documents, including, as needed, constitutions, central bank laws, banking laws, and other laws or regulations that may have a bearing on central bank mandates, policies or operations.

- Central banks' publications, pronouncements, and other documents released to the public, as found on central banks official websites and other media (e.g., official gazettes) as necessary.

- MFPT assessments carried out since the GFC by IMF staff or publicly available self-assessments (e.g., Japan).

- Information collected from Fund technical assistance reports to the countries in the sample.

- Information available from the IMF's Central Bank Legislation Database (CBLD).

- Selected academic research of central bank governance and transparency practices in the sample countries (see References and Bibliography).

22. The CBT modular framework proved to be sufficiently robust to capture the nuances of diverse central banking environments and to serve as a foundation for developing the new CBT. While the individual country analyses are not intended to be an assessment methodology, they nevertheless provided useful insights for later developing a methodology that can be used to evaluate transparency practices in central banks of Fund member countries under the new CBT.

\footnotetext{
${ }^{14}$ The group comprised the central banks for the following countries: Angola, Argentina, Australia, Canada, Chile, Colombia, Czech Republic, Georgia, Honduras, Hungary, Iceland, Japan, Jordan, Kyrgyz Republic, Malaysia, Morocco, Rwanda, Singapore, South Africa, Sweden, Thailand, Uganda, United Kingdom, and Uruguay.
} 


\section{To get a general sense of current transparency practices in the central banks of the} sample, staff aggregated the results of the individual transparency analysis. ${ }^{15}$ Figure 6 and Table 1 present a high-level summary of the results from this exercise. ${ }^{16}$ As Figure 6 shows, the central banks in the sample seem fairly transparent in the areas related to their governance (Pillar I), policies (Pillar II), and official relations (Pillar V). However, central banks appear to be somewhat less transparent when it comes to their operations (Pillar III) and, especially, the outcome of those operations (Pillar IV). This seems to be primarily related to differences in the modalities used by central banks to explain their monetary policy operations and other activities, including in areas such as payments system. Transparency related to activities or outcomes of non-traditional objectives is even less common. For example, reporting to parliament, other relevant public bodies or the public, on the outcomes of financial integrity and consumer protection programs is rare, including in central banks that have a legal mandate to implement such programs.

\section{The exercise also suggest that transparency gaps are more prevalent in newer central} bank mandates. The contrast is notable, in particular, between the relatively high transparency in the traditional micro- and macro-prudential areas and the lower transparency in less traditional mandates (e.g., resolution, financial integrity, and consumer protection). There also seems to be a large variance in transparency practices related to ELA operations.

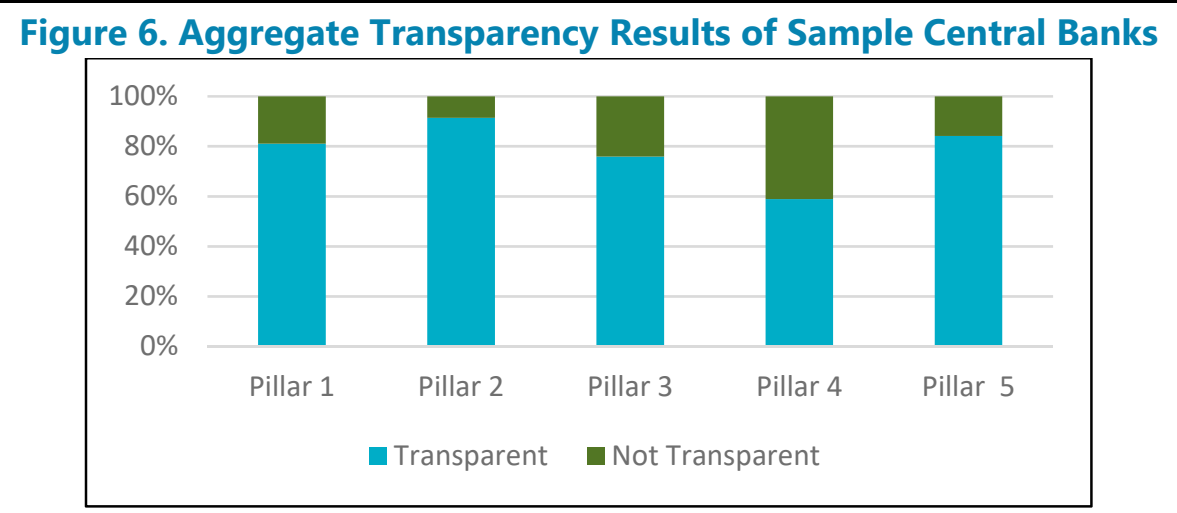

Source: IMF Staff Estimates.

\footnotetext{
${ }^{15}$ For the purpose of this exercise, overall transparency of central banks was calculated as the simple average of the binary scores (transparent: "yes," not transparent: "no") given to every module without assigned weights. This simple procedure seems to present a broadly clear picture for Pillars II to V. In the case of Pillar I, however, a, more granular examination of the different "transparency in governance" components is necessary to ensure that a simple average does not produce biased results. Detailed examination of other pillars can be found in Annex II.
}

${ }^{16}$ See Annex II for a more detailed presentation of the findings of the exercise, including a breakdown of findings within each of the CBT framework pillars. 


\begin{tabular}{|c|c|c|c|c|}
\hline Pillar I. Governance & Pillar II. Policies & Pillar 3. Operations & Pillar IV. Outcome & Pillar V. Official Relations \\
\hline $\begin{array}{l}\text { Legal Status } \\
\text { Broad transparency of legal status but much less regarding } \\
\text { staff immunities and gaps in transparency in legal } \\
\text { framework. }\end{array}$ & \multirow{7}{*}{$\begin{array}{l}\text { Broad } \\
\text { transparency of } \\
\text { monetary, macro } \\
\text { and micro- } \\
\text { prudential and } \\
\text { payment systems } \\
\text { policies. Some } \\
\text { gaps with respect } \\
\text { to ELA, } \\
\text { resolution, } \\
\text { financial integrity } \\
\text { and consumer } \\
\text { protection (where } \\
\text { applicable). }\end{array}$} & \multirow{7}{*}{$\begin{array}{l}\text { Broad transparency of } \\
\text { monetary and payment } \\
\text { systems operations, and, } \\
\text { to a lesser extent, micro- } \\
\text { and macro-prudential } \\
\text { operations and resolution. } \\
\text { Important gaps exist with } \\
\text { respect to ELA, financial } \\
\text { integrity and consumer } \\
\text { protection (where } \\
\text { applicable). }\end{array}$} & \multirow{7}{*}{$\begin{array}{l}\text { Broad transparency of } \\
\text { the outcomes of } \\
\text { monetary policy and, } \\
\text { to a lesser extent, } \\
\text { financial policies; but } \\
\text { much less with } \\
\text { respect to ELA, } \\
\text { resolution, financial } \\
\text { integrity and } \\
\text { consumer protection } \\
\text { (where applicable). }\end{array}$} & \multirow[t]{7}{*}{$\begin{array}{l}\text { Broad transparency of } \\
\text { relationships with government, } \\
\text { with the notable exception of } \\
\text { transparency about credit to } \\
\text { government. }\end{array}$} \\
\hline $\begin{array}{l}\text { Mandate } \\
\text { Transparency of price stability and payment systems; high } \\
\text { transparency of micro- and macro-prudential respectively; } \\
\text { less of ELA, financial integrity and consumer protection. }\end{array}$ & & & & \\
\hline $\begin{array}{l}\text { Autonomy } \\
\text { High transparency of functional and financial autonomy; } \\
\text { less of institutional and personal autonomy. }\end{array}$ & & & & \\
\hline $\begin{array}{l}\text { Decision-Making Arrangement } \\
\text { Broad transparency of decision-making structures for price } \\
\text { stability and micro- macro-prudential; less of fin. integrity, } \\
\text { and consumer protection. }\end{array}$ & & & & \\
\hline $\begin{array}{l}\text { Risk Management } \\
\text { Broad transparency of internal risk management policies, } \\
\text { but few gaps regarding risk decision-making structures. }\end{array}$ & & & & \\
\hline $\begin{array}{l}\text { Internal Accountability } \\
\text { Broad transparency of financial statements and reporting to } \\
\text { government. Generally, no publication of the audit report. } \\
\text { Broad transparency of lacking ethics/Code of Conduct } \\
\text { requirements. }\end{array}$ & & & & \\
\hline $\begin{array}{l}\text { Communication } \\
\text { Broad transparency of communication strategy and policy, } \\
\text { and confidentiality rules. }\end{array}$ & & & & \\
\hline
\end{tabular}




\section{SUMMARY AND NEXT STEPS}

25. This paper contains a staff proposal to revise the 1999 MFPT. The paper responds to a request made by the Executive Board at the time of the $2017 \mathrm{RSCl}$.

26. Staff proposes to replace the MFPT with a CBT code. The proposed CBT enhances the efficiency of Fund work by eliminating the overlap with FSB standards approved since the MFPT was created, improves the general effectiveness of Fund work by expanding the transparency criteria to the broader set of activities undertaken by central banks since the GFC, and creates costeffectiveness in particular by facilitating risk-based assessments to support policy effectiveness and address macroeconomic risks.

27. Developing the CBT as proposed in this paper will entail several steps. These would include: (1) preparing a draft code and an assessment methodology building on the framework presented in this note (MCM in collaboration with FIN, LEG, SPR, and STA); (2) convening an international advisory group comprised of former central bank governors and international experts (including, as needed, from relevant other international institutions) to provide guidance and feedback to draft code and methodology; (3) extensive consultation with Executive Directors; (4) developing a clear timetable for Board discussions of the new code; and (5) carrying out pilot assessments.

\section{ISSUES FOR DISCUSSION}

- Do Directors agree with staff's proposal to replace the MFPT with the CBT based on the framework advanced in this paper?

- Do Directors agree with the five-pillar framework proposed to assess the transparency of central banks?

- Do Directors support that staff convenes an international advisory group to provide guidance to staff in the elaboration of the new code? 


\section{References}

BCBS, 2011, Core Principles for Effective Banking Supervision. Basel: Bank for International Settlements.

BIS, 2009, Issues in the Governance of Central Banks-A Report from the Central Bank Governance Group. Basel: Bank for International Settlements.

BIS, 2011, Central Bank Governance and Financial Stability. Basel: Bank for International Settlements.

Dincer, N., B. Eichengreen. 2014, Central Bank Transparency and Independence: Updates and New Measures, International Journal of Central Banking, Vol. 38(3), pp. 189-253.

Dobler, M., e.a., 2016, The Lender of Last Resort Function after the Global Financial Crisis, IMF Working Paper 16/10. Washington: International Monetary Fund.

FSB, 2014, Key Attributes of Effective Resolution Regimes for Financial Institutions. Basel: Bank for International Settlements.

IMF, 1999, Code of Good Practices on Transparency in Monetary and Financial Policies: Declaration of Principles. Washington: International Monetary Fund.

IMF, 2000, Supporting Document to the Code of Good Practices on Transparency in Monetary and Financial Policies, Part 1-Introduction. Washington: International Monetary Fund.

IMF, 2000, Supporting Document to the Code of Good Practices on Transparency in Monetary and Financial Policies, Part 2-Good Transparency Practices for Monetary Policy by Central Banks. Washington: International Monetary Fund.

IMF, 2000, Supporting Document to the Code of Good Practices on Transparency in Monetary and Financial Policies, Part 3-Good Transparency Practices for Financial Policies by Financial Agencies. Washington: International Monetary Fund.

IMF, 2011, "The 2011 Joint Review of the Standards and Codes Initiative," February 16, 2011. Washington: International Monetary Fund.

IMF, 2013, "Key Aspects of Macroprudential Policy," June 10, 2013. Washington: International Monetary Fund. 
IMF, 2014, Macroeconomic Developments in Low-Income Developing Countries, IMF Policy Paper. Washington: International Monetary Fund.

IMF, 2015, Evolving Monetary Policy Frameworks in Low-Income Countries and Other Developing Countries. Washington: International Monetary Fund.

IMF, 2017, "The 2017 Joint Review of the Standards and Codes Initiative," August 3, 2017. Washington: International Monetary Fund.

IMF, 2018a, The IMF's Annual Macroprudential Policy Survey, April 2018. Washington: International Monetary Fund.

IMF, 2018b, Review of 1997 Guidance Note on Governance-A Proposed Framework for Enhanced Fund Engagement. Washington: International Monetary Fund.

IMF, 2019, Review of the Fund's Strategy on Anti-Money Laundering and Combating the Financing of Terrorism, Staff Report, February 2019. Washington: International Monetary Fund.

Khan, A., 2017, Central Bank Legal Frameworks in the Aftermath of the Global Financial Crisis, IMF Working Paper 17/101. Washington: International Monetary Fund. 


\section{Annex I. Central Bank Transparency Framework}

\section{This annex describes the categories and concepts used in each of the five pillars of the proposed CBT framework.}

\section{Pillar I. Transparency in Governance}

\section{I.1. Legal Status}

1. Information provided to the public regarding:

a. the central bank's legal framework;

b. its legal personality; and

c. general considerations on central bank immunity/liability, legal protection of central bank decision-makers and staff, with particular reference to whether these individuals may be subject to legal suits/liability for any adverse consequences of decisions made under the course of conducting their official duties.

\section{I.2. Mandate}

2. This relates to three components, namely: (a) objectives, (b) functions (tasks) and (c) instruments (tools), defined in relevant legislation or regulation. This allows central banks to reveal what they are trying to achieve, the fundamental principles governing their actions and any changes in objectives.

a. Objectives are the goals that the central bank aimto accomplish. It is well-established practice that central bank laws identify price stability_or a similar concept-as a primary (or one of the main objectives) of the central bank. Many central banks may have other objectives as part of their mandate, including economic (e.g., support the economic policies of the government, full employment, economic growth, financial inclusion, etc.), often subordinated to the price stability objective, and can also have financial stability (micro- and macro-prudential), financial integrity (relating to ensuring compliance with AML/CFT aspects), and consumer protection objectives.

b. Functions (tasks) are the activities that the central bank undertakes to achieve these goals. In addition to the traditional function of monetary policy, central bank laws and other relevant laws typically establish core functions which are often related to a specific central bank objective.

c. Instruments (tools) are the instruments at the disposal of a central bank to implement its functions. These instruments can be of a private and public law nature: 
i. Typical private law instruments are the explicit authorization (a) to enter into a wide range of financial contracts, (b) to take deposits of cash and securities, and (c) to take and enforce collateral (sometimes under a special regime).

ii. Public law instruments can include the authorization to (a) issue legally-binding regulatory instruments (such as the imposition of ceilings on commercial banks' lending, minimum reserve requirements, etc.) and (b) the power to impose administrative sanctions in case of breach of normative obligations.

\section{I.3. Autonomy (Independence)}

3. Central bank autonomy or independence (Box 1) relates to four core areas: (a) functional, (b) institutional (operational), (c) personal, and (d) financial.

\section{Box 1. Terminology Note: "Autonomy" vs Independence}

"Independence" is the legal term used in the majority of central bank legal frameworks, but with some variations. The European System of Central Banks Statute uses "independence," though only as a section title, not in the text that follows it. A number of countries (e.g., Dominican Republic, Iraq, and Slovenia,) use "independence" in their constitution, but "autonomy" in the central bank law (Macedonia has it the other way around). Some countries combine independence and autonomy in the same sentence. For example, in Liberia the central bank law specifies an "independent central bank with autonomous regulatory powers." Discussions in relevant literature highlight the difficulty of defining independence vs. autonomy (see, for instance, BIS, 2009, Issues in the Governance of Central Banks - A Report from the Central Bank Governance Group (Basel: Bank for International Settlements), and BIS, 2011, Central Bank Governance and Financial Stability. Basel: Bank for International Settlements.

Additionally, central bank legislation shows a difference in using adjective and noun forms. When independence and autonomy are used as adjectives, i.e., "independent" and "autonomous", they would appear to be referring to a narrower context than that of the central bank as a whole. Similarly, some laws refer to the narrower context of "financial autonomy" only.

It is also possible that the terms are used interchangeably, used without an intended distinction in meaning, or face translation issues from the original drafting language.

For the purposes of this paper, the word "autonomy" will be used throughout, notwithstanding specific legal frameworks and/or discussions.

\section{Functional Autonomy}

4. Central bank autonomy is not an end in itself but is instrumental in achieving the central bank's mandate. This could include a prohibition for third parties to approve, suspend, annul, or defer central bank decisions. In addition, it could have separate legal personality and have the necessary private and public law instruments to implement its functions without the government having to approve or adopt specific instruments necessary for the central bank's functioning. Also, 
there would ideally be clarity on which other legislation is applicable to the central bank and the latter should be consulted prior to the adoption of any legislation that might affect it. ${ }^{1}$

\section{Institutional (operational) Autonomy}

5. This aspect of central bank autonomy focuses on the legal prohibition for a central bank and the members of its decision-making bodies to seek or take instructions from any public or governmental authority and from any other (including commercial) body. It also deals with authorities and bodies being explicitly prohibited from seeking to influence the central bank, and the members of its decision-making bodies whose decisions may affect the fulfillment of the central bank's mandate. Finally, it relates to the representatives of third parties being excluded from voting when they participate in central banks' decision-making bodies. ${ }^{2}$

\section{Personal Autonomy}

6. This relates to adequate safeguards that shield the personal autonomy of key central bank officials from political and private economic interests. These safeguards could include the following considerations:

a. The minimum term of office for these central bank decision-making officials being longer than the electoral cycle in the respective country.

b. More than one authority being involved in their appointment, respectively dismissal (socalled double veto procedure).

c. Robust eligibility criteria and incompatibility requirements being in place to facilitate the appointment of persons of high competencies and integrity to a central bank's decisionmaking bodies and prohibit government and political officials from such appointment (at least as full voting members).

d. Strong grounds to protect key officials from arbitrary dismissal by a requirement that they can only be relieved from office if they no longer fulfill the conditions required for

\footnotetext{
${ }^{1}$ See Lybek, T., J. Morris, 2004, Central Bank Governance: A Survey of Boards and Management, IMF Working Paper 04/226.

2 The Basel Committee on Banking Supervision's Core Principles for Effective Banking Supervision; September 2012 clarifies in its Principle 2 that the supervisor should have "operational independence". Essential criterion 1 adds that "there is no government or industry interference that compromises the operation al independence of the supervisor. The supervisor has full discretion to take any supervisory actions or decisions on banks and banking groups under its supervision." The IMF's concept of institutional autonomy is in line with this Essential criterion. A similar criterion of operational independence for a Resolution Authority is specified in paragraph 2.5 of the Financial Stability Board's Key attributes of effective Resolution Regimes for Financial Institutions; October 2014.
} 
the performance of their duties, or if they have been found guilty of serious misconduct, whilst having due process, including judicial recourse, in the event of a dismissal. ${ }^{3}$

\section{Financial Autonomy}

7. A central bank's autonomy could be jeopardized insofar as it cannot continuously avail itself of sufficient financial resources to fulfill its mandate. ${ }^{4}$ Financial autonomy implies that the central bank (as per the central bank law) has sufficient financial resources and is automatically recapitalized in case its capital falls below its authorized capital.

8. The central bank law contains clear rules on the determination of a central bank's budget and mandate the central bank to establish the adequate level of provisions and reserves (including the possibility of dynamic capital), as well as rules on distribution of dividends to the government. ${ }^{5}$ Additionally, financial autonomy also refers to the (full or in part) prohibition of, or clear limitations on, loans to government, other public entities, and other forms of (quasi-) fiscal financing.

\section{I.4. Decision-Making Structure}

9. For the purposes of this paper, this relates to the organizational structure or hierarchy of decision-making bodies of the central bank which is responsible for (a) policy making, (b) day-today management, and/or (c) internal oversight of the central bank, including board of directors, committees, or any other governing body of the central bank, established by law or regulation.

\section{I.5. Internal Accountability}

10. This deals with the availability of an internal accountability framework, which includes (a) clearly defined frameworks for internal audit (and internal audit findings), risk management, compliance (including an ethics and/or anticorruption framework for central bank decision-makers and staff), and external audit (including clarity on accounting and reporting standards); (b) the legal requirement to report to the Board (or other decision-making body), and/or its Audit Committee, on matters of internal and external audit, risk management, and compliance; as well as (c) the external

\footnotetext{
3 The IMF's concept of personal autonomy is in line with Essential criterion 2 of the Basel Committee on Banking Supervision's Core Principle 2 on operational independence. It provides that "the process for the appointment and removal of the head(s) of the supervisory authority and members of its governing body is transparent". It adds the need for appointments for a minimum term and to remove the head(s) of the supervisory authority and members of its governing body "only for reasons specified in law."

4 The IMF's concept of financial autonomy is in line with Essential criterion 6 of the Basel Committee on Banking Supervision's Core Principle 2 on operational independence. It provides that "the supervisor has adequate resources for the conduct of effective supervision and oversight." The Financial Stability Board's criterion of operational independence for a Resolution Authority similarly stresses the need for Resolution Authorities to have the "resources and the operational capacity" to effectively implement their functions (paragraph 2.5 of the Financial Stability Board's Key attributes of effective Resolution Regimes for Financial Institutions).
}

${ }^{5}$ This often includes the prohibition of distribution of unrealized gains as part of the central bank's net profits. 
publication of (but not limited to) financial statements, annual reports, and standards for the conduct of personal financial affairs.

\section{I.6. Risk Management Systems}

11. Risk management in the broadest sense is defined as "the coordinated activities to direct and control an organization with regard to risks" (ISO 31000 guide 73:2009, Risk Management Vocabulary). Transparency on risk management relates to the risk appetite and its framework: the overall approach, including statement, policies, processes, controls, and systems through which the risk appetite is established, communicated, and monitored. ${ }^{6}$ Risk management covers both financial and nonfinancial risks. A risk appetite statement could be a written, published, and widelycommunicated document, referring to the amount and type of risk that a central bank is willing to take to meet their strategic objectives.

\section{I.7. Communication Strategy and Policy, Public Information Services including Secrecy and Confidentiality Framework}

12. The communication strategy covers the means and methods of internal and external communication used by the central bank and the forms of disclosure of information to its stakeholders. Public information services established by the central bank, including a publication program, would be in accordance with relevant legislation. Those services are aimed the central bank being accessible and effective in reaching stakeholders and supporting central banks functions and objectives. This also includes aims and means of communication by public officials set in law, guidelines, or regulations, as well as published data management systems, general procedures, and rules.

13. Laws and/or regulations would contain the central bank's policy on confidentiality or secrecy of central bank information, or its non-disclosure policy of its operations in law or regulation. Laws or regulations cover when central bank decision-makers and/or staff are required to keep secrecy and under what conditions confidentially of information is classified as such. This includes prohibitions from disclosing confidential information provided by a third person to the central bank or elaborated on by the central bank itself. It also includes specific disclosure or non-disclosure frameworks or regulations for high ranking central bank officials and/or central bank decisionmakers.

\footnotetext{
${ }^{6}$ FSB, 2013, Principles for An Effective Risk Appetite Framework. Basel: Bank for International Settlements.
} 


\section{Pillar II. Transparency in Policies}

Pillar II refers, in general, to public availability of information on monetary and financial policies, within the mandate of the central bank, and how these are publicly disclosed or published.

\section{II.1. Policy Decisions}

14. This refers to the policy decisions, whether new actions or changes to standing policies, announced at the time, or soon after they occur, including public statements on the policy objective, rationale, and potential impact.

\section{II.2. Supporting Analysis}

15. Supporting analysis refers to the publication of the in-house analysis underlying the policy decisions to achieve the intended policy objectives.

\section{II.3. Decision-Making Process}

16. Disclosure of procedural actions, which can include the way monetary, foreign exchange and financial policy decisions are taken; deliberations, means, and methods of reaching a decision; and minutes, voting, records of governing bodies, as well as any relevant public consultation process.

\section{Coverage of Policies}

17. The scope of central bank policies is determined by its mandate, de jure and de facto. All central banks have monetary policy as a primary responsibility, but broad variations exist with respect to financial policy responsibilities related to financial stability, integrity and consumer protection. Notwithstanding this diversity, the three elements constituting the transparency in policies pillar: policy decisions, supporting analysis, and decision-making process are relevant and are applied to all policies pursued by central banks.

\section{Monetary Policy}

18. This refers to the central bank's description of and explanation to the public of the framework, instruments, and methods (data, models, forecasts, and simulations) used to pursue the objectives of monetary policy. This includes announcements regarding changes in monetary policy at the time or soon after they occur and the issuance of public statements on progress made towards achieving the central bank's monetary policy objectives. Policies include actions on reserve requirements, conditions of lending, as well as credit and interest rate controls. 


\section{Financial Stability}

19. This includes general considerations regarding the disclosure of overlapping responsibilities among different institutions and the allocation of responsibilities or cooperation on policy and operations related to the financial stability objective.

20. Macroprudential Framework: roles and responsibilities that allow the central bank to wholly or jointly with other institution(s) establish the macroprudential policies and tools to mitigate systemic risk in legislation or regulations. This includes central bank policies to monitor financial stability risk in different sectors of the economy; exposures of the banking system to households and to nonfinancial firms, liquidity risks, and foreign exchange mismatches in the banking sector; systemic liquidity risks and fire sale risks in the nonbank financial sectors; and risks from systemically important institutions and interconnectedness within the financial system.

21. Microprudential supervision: the responsibility of the central bank wholly or jointly with other institution(s) on general policies regulating financial institutions, such as licensing and registration, and the institutional arrangements to implement its supervisory power, as disclosed in legislation. This includes methods used to supervise financial institutions; the exchange of information between the central bank and financial institutions; and any sanctions regime to which financial institutions are subject to and is implemented by the central bank.

22. ELA: Emergency Liquidity Assistance framework established or used by the central bank to provide central bank money to solvent financial institutions that are facing temporary liquidity problems, as disclosed in legislation or central bank regulations and disclosed to stakeholders.

23. Resolution: the framework that allows the central bank to deal with failing banks that pose a risk to the financial system and encompasses measures to minimize negative impacts in the financial environment, including preventive measures to avoid failure of a financial institution, and as established in legislation.

24. Payment and Securities Settlement System: the policy and policy formulation by the central bank of its oversight responsibility, and as established by law or resolutions known by its stakeholders.

\section{A. Financial Integrity}

25. Policies and measures taken wholly or jointly with other institution(s) by the central bank to assure transparency and ethical practices on financial transactions, anti-money laundering mandate and functions, anti-terrorism financing functions and practices, anti-corruption mechanisms in financial transactions, and financial inclusion mechanisms that directly promote financial integrity. This could also include the role of a Financial Intelligence Unit (FIU). 


\section{B. Consumer Protection}

26. The legal framework, institutional arrangement(s), and mandates for supervisory activities and enforcement by the central bank on consumer protection. This includes disclosure measures and transparency of financial institutions to the public, fair treatment and business conduct, data protection and privacy usage of customer data, or practices in information-sharing and dispute resolution mechanisms.

\section{Pillar III. Transparency in Operations}

Pillar III refers to transparency of central banks conduct as they implement their policies, and relates to instruments used, the scope of operations, and rules of access.

\section{III.1. Instruments}

27. Transparency of instruments involves clear and public articulation of (a) the set of instruments that the central bank uses to implement its policies; (b) the techniques of applying those instruments; and, (c) the rules under which these operations are conducted.

\section{III.2. Coverage}

28. This relates to the scope of central bank operations, in the pursuit of the central bank's policy objectives. This includes targeted markets and financial institutions that are accredited based on licensing criteria, as defined by law or regulation.

\section{III.3. Access}

29. This relates to clear rules, that are well known, regarding access to, use of, and interaction with central bank instruments by accredited financial institutions.

\section{Coverage of Operations}

30. This relates to central banks ensuring that their operational frameworks reflect their de jure and de facto mandates and are transparent to the public in terms of instruments, coverage and access.

31. Monetary policy. Central Bank transmittal of information to stakeholders on monetary policy instruments and any targets (procedures and practices) that are used to pursue the central bank's objective(s), including, inter alia, open market operations, central bank discount and deposit facilities, disclosure of foreign exchange transactions, international reserves management and foreign exchange operations (including assets and liabilities). ${ }^{7}$

\footnotetext{
${ }^{7}$ FX operations are often conducted after a predetermined interval disclosure of selected information on its aggregate market transactions
} 
32. Macroprudential measures. These could include countercyclical capital buffers, or forwardlooking loan loss provisioning requirements, restrictions on loan-to-value and debt-service-toincome ratios, additional capital requirements on loans to corporate sector, or higher capital requirements for lending in $\mathrm{FX}$, or tools to manage liquidity and FX mismatches in the banking system, and tools to manage systemic liquidity arising in the non-bank financial sector, additional capital surcharges for systemically important financial institutions-all of which as disclosed in laws or regulations.

33. Microprudential Supervision. This relates to the implementation of the central bank's supervisory function and the disclosure of information on measures taken in this capacity. This also includes a possible non-disclosure policy, as established by law.

34. Resolution. Measures implemented by the central bank aiming to avoid financial institutions' failure or crisis, and/or a non-disclosure policy as established in legislation.

35. ELA. Disclosure of central bank operations established to provide liquidity assistance to financial institutions, under appropriate safeguards, and possible communication to parliament.

36. Payment systems. Disclosures relating to the oversight function and operation of the payment system.

\section{Pillar IV. Transparency in Outcome}

Pillar IV relates to reporting requirements of the central bank's governing bodies (including the governor) to the executive branch, parliament/the legislative power, and the public at large primarily about the policies and decisions adopted by the central bank to achieve its policies or objectives. This also includes the implications of not reaching the desired objectives.

37. This also includes information on officials of the central bank when appearing before a designated public authority to report on the conduct of monetary policy, issues of financial stability, financial integrity, consumer protection, or payment systems should describe the central bank performance in achieving its objectives and exchange views on the state of the economy and financial system. 


\section{Pillar V. Transparency in Official Relations}

Pillar $V$ deals with the relationships of the central bank with official bodies of relevance for the central bank's policy effectiveness and accountability. This includes relationships with the government (at all levels), other public institutions (e.g., financial supervisory agencies), and foreign entities (e.g., other central banks, international organizations,), as well as the relevant legal frameworks.

\section{V.1. Government}

38. This relates to the important relationship of the central bank with government as its financial adviser, banker, and financial agent. Transparency in this regard includes public disclosure of policies allowing or prohibiting credit to the government, and if allowed, the conditions under which the central bank lends to the government, as well as the. disclosure of these on a timely basis, including the amount, interest rate, and maturity of the loans, such that markets can internalize any potential impact on systemic liquidity. This also includes consultation mechanisms with the government.

\section{V.2. Other Public Agencies}

39. This relates to the exchange of information between the central bank and public-sector institutions, particularly agencies with financial sector oversight responsibilities, and other cooperation agreements.

\section{V.3. International}

40. This relates to information on international or bilateral relationships that serve an economic or financial objective, and may give rise to mandatory obligations (e.g., cross border supervision, IMF Article IV), voluntary actions (e.g., SWAP lines), or consultative relationships. 


\section{Annex II. Central Bank Transparency Framework: Case Studies}

This annex presents the results of the application of the proposed CBT framework to the sample set of 24 central banks listed in footnote 14. For each category, the individual assessments were aggregated following the methodology described in footnote 15.

\section{Pillar I. Transparency in Governance}

\section{Legal Status}

1. All central banks are transparent about their legal personality. Legal personality is always defined in the central bank law. Most central banks are also transparent about the legal framework governing the central bank in general (which includes, for instance, the constitution, the central bank law, and other laws such as related to financial supervision), though there are a few cases where transparency is lacking.

\section{Only a small number of central banks is transparent about legal immunities for their} management and staff. Immunities relate to legal protection measures for central bank management and staff, and/or others, in terms of excluding legal liability and/or offering legal indemnification in case of liability. Only a few central banks are transparent about whether such immunities are offered. Most central banks are not transparent about possible legal protection, or it is simply not clear from the central bank law and/or the central bank's website (Figure 1). It similarly notes that out of 143 countries and monetary unions of which the central banks laws are listed in the IMF's CBLD, only 53 percent contains at least one explicit reference to liability arrangements. This could be because domestic laws (other than the central bank law) make arrangements that also apply to the central bank (management and staff). Nonetheless, central banks clearly are not transparent about this on their own websites.

Figure 1. Central Bank Transparency on Legal Status of the Central Bank

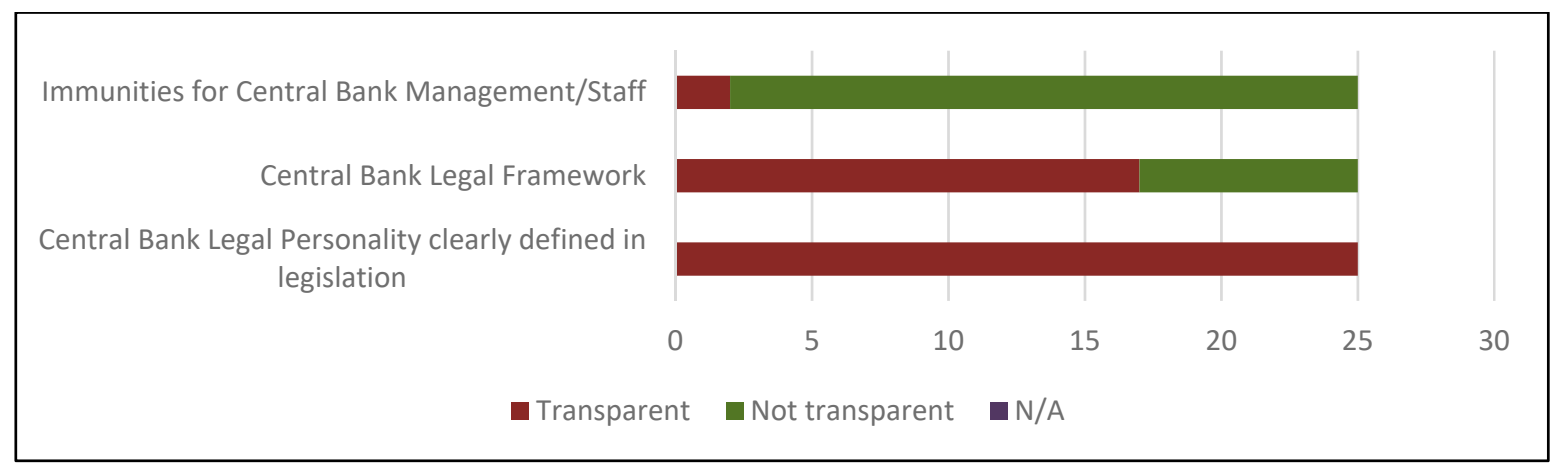

Source: IMF Staff. 


\section{Central Bank Mandate}

\section{All central banks are transparent regarding their price stability and payment systems} objectives. The overarching transparency arrangements for these two objectives are embedded in the central bank law. However, for ELA as a financial stability function, not all central banks offer full transparency. Arrangements for this function are highlighted by most central banks in central bank laws, but there are several situations where it is not fully clear if other laws provide a mandate to the central bank, and/or whether there are ad hoc arrangements. ${ }^{1}$ It is imaginable that authorities could allow for ambiguous transparency arrangements surrounding ELA to counter possible moral hazard. ${ }^{2}$ Finally, ad hoc responsibilities are also quite common for central banks with a consumer protection function, and in an occasional case for the financial integrity function. Note that for some objectives multiple laws (referred to in Figure 2 as "CB Law" and "Other Law") contain arrangements-mostly in the case of micro and macroprudential supervision, and payments systems.

Figure 2. Central Bank Transparency on Mandate

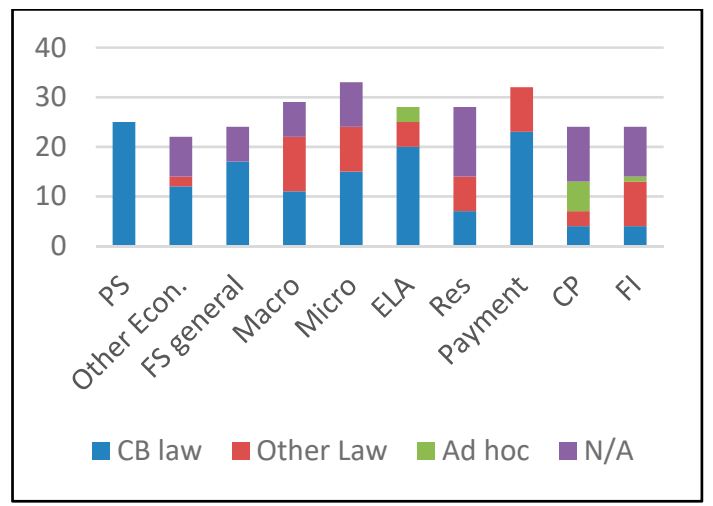

PS: Price Stability

Other Econ: Other economic objective

FS general: General Financial Stability

Objective

Macro: Macroprudential Supervision

Micro: Microprudential Supervision

Source: IMF Staff.

\section{Central Bank Autonomy}

4. Transparency on functional and financial autonomy is well-established, but less on institutional autonomy. Near to all central banks are transparent about their functional and financial autonomy (see Annex I for descriptions of the different forms of autonomy). This is also the case for little more than half of the central banks regarding personal autonomy, and less than half for institutional/operational autonomy. The latter is remarkable, as the Basel Core Principles for Effective Supervision require financial supervisors to have operational autonomy, and most central

\footnotetext{
1 "Ad hoc arrangements" refer to situations where the central bank indicates it has a specific objective that is not (clearly) laid down in the central bank law, or any other relevant law, but which it nevertheless considers as part of its mandate.

2 Dobler, M., e.a., 2016, The Lender of Last Resort Function after the Global Financial Crisis, IMF Working Paper 16/10. Washington: International Monetary Fund.
} 
banks are also financial supervisors. The fact that central banks still seem to be lacking in their transparency on operational autonomy, could be because those arrangements are likely embedded in another law than the central bank law (for instance, a banking services law). Nonetheless, central bank/financial supervisors would still need to be transparent about operational autonomy arrangements, regardless of the legal source. The same holds for personal autonomy, where little more than half of the central banks are transparent about their personal autonomy, as opposed to a considerable number (slightly less than half) of central banks that are not (Figure 3).

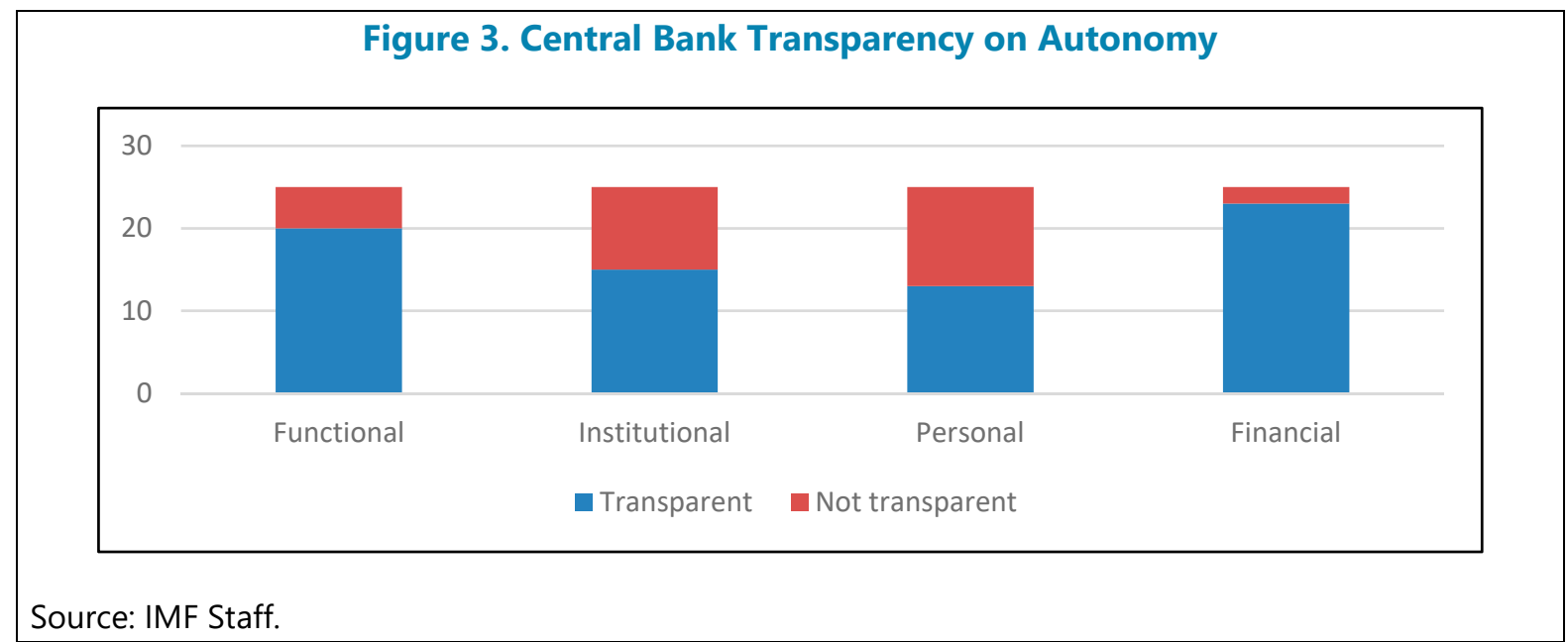

\section{Central Bank Decision-Making Structures}

5. Next to all central banks are transparent about their decision-making structures. The central bank Board/Council ${ }^{3}$ is most often the key decision-making body, specifically for the objectives of price stability and payment systems (Figure 4), even if dedicated decision-making bodies for monetary and macroprudential functions are also common. In one case, the central bank was not transparent about its decision-making structure for resolution. For resolution, as well as for financial integrity and consumer protection, many central banks indicate that institutional arrangements are not applicable to them. This is likely because they do not have a mandate in these areas-and they are transparent in indicating so.

\footnotetext{
3 The terminology for the highest decision-making body of a central bank can differ. Some central banks have a "Board", others a "Council", some central banks have both - the important distinction is between the functions that such a body may have. For the purpose of this paper that distinction is, however, left out of scope. The Board or Council in these cases may be responsible for policy decision-making, day-to-day management, or oversight, or a combination of these functions.
} 
Figure 4. Transparency on Central Bank Decision-Making Structures
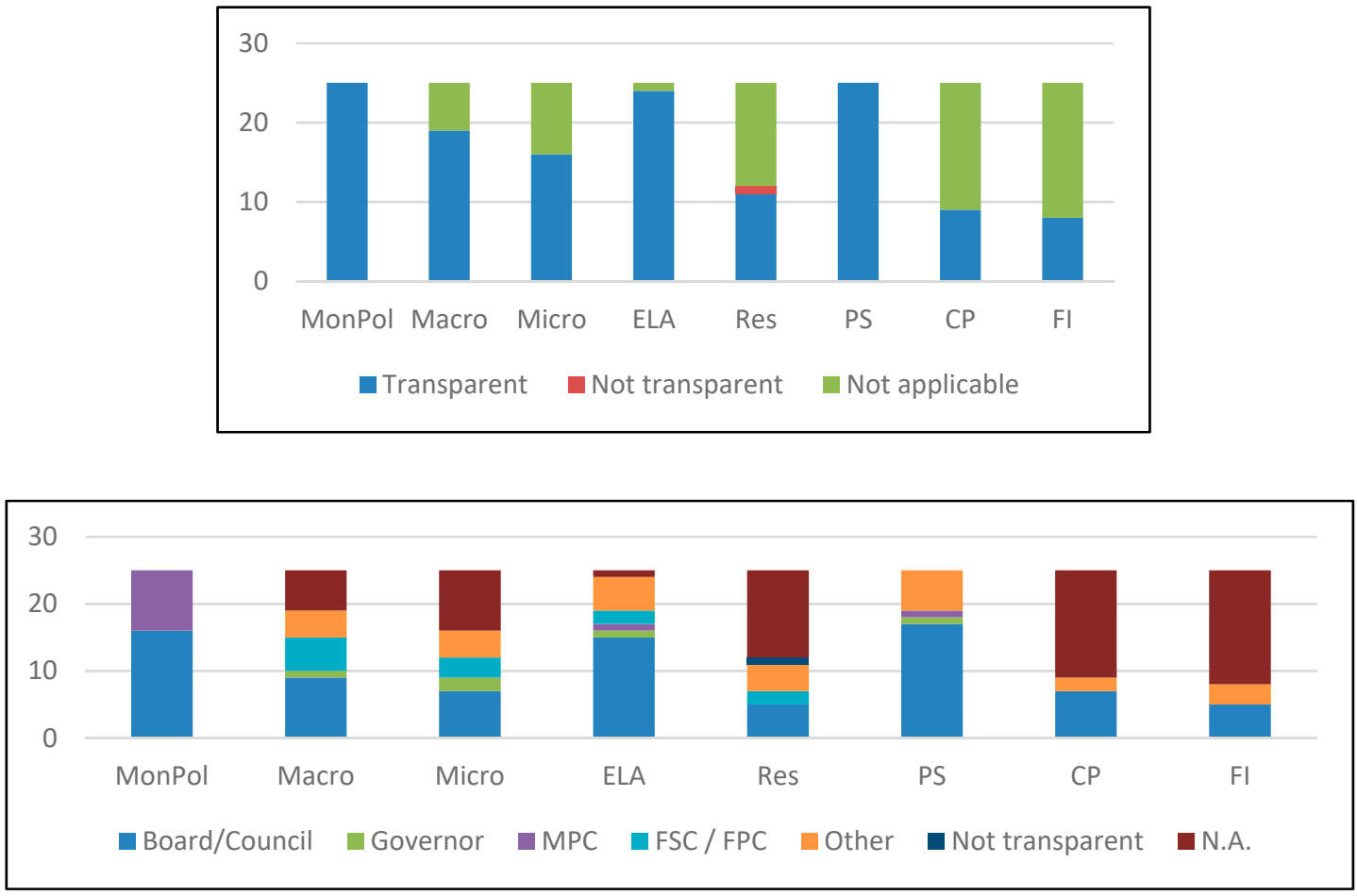

Source: IMF Staff.

\section{Central Bank Internal Accountability}

\section{Most central banks are transparent about their financial statements and annual}

reporting to government. Central bank laws or websites provide information on the duty of central banks to submit their annual report, as well as annual statements, to government. In near to all cases, this is done based on a legal obligation, though in two cases it is not clear if there is such a legal obligation (Figure 5).

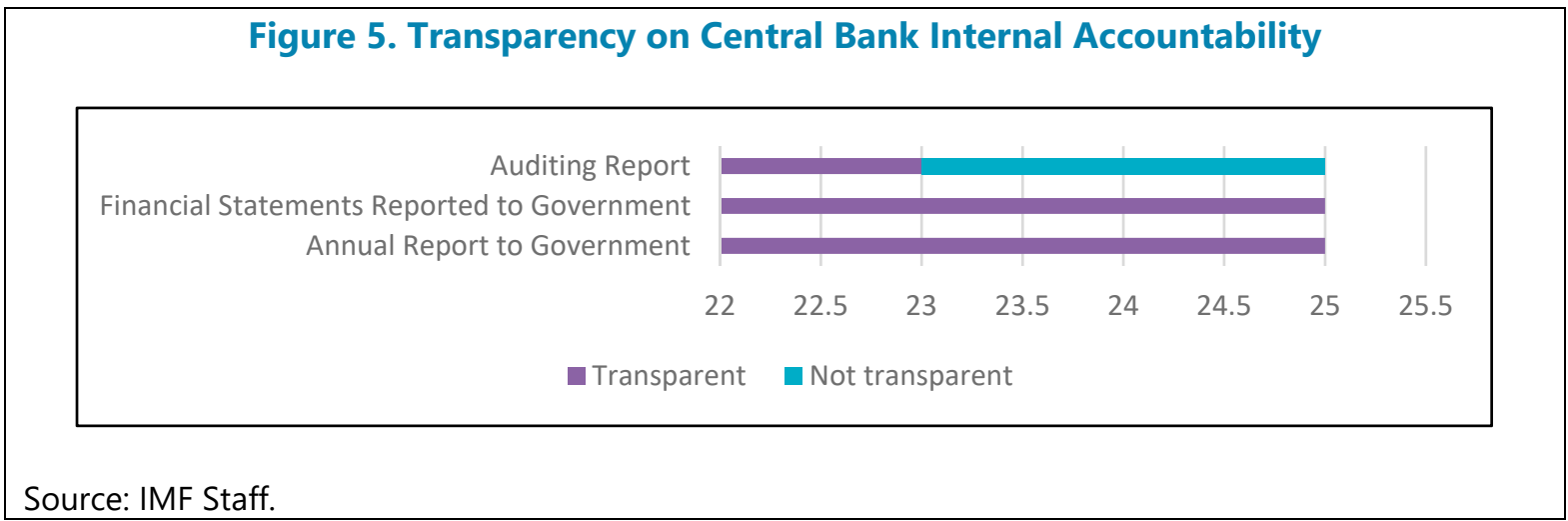




\section{All central banks are transparent about whether they publish an annual report and} report financial statements to government. In only two cases is the central bank not transparent about whether it publishes some/a summary of its audit report findings, which in most of those cases is based on an explicit legal obligation (Figure 6).

Figure 6. Transparency on Central Bank Accountability - Legal obligation

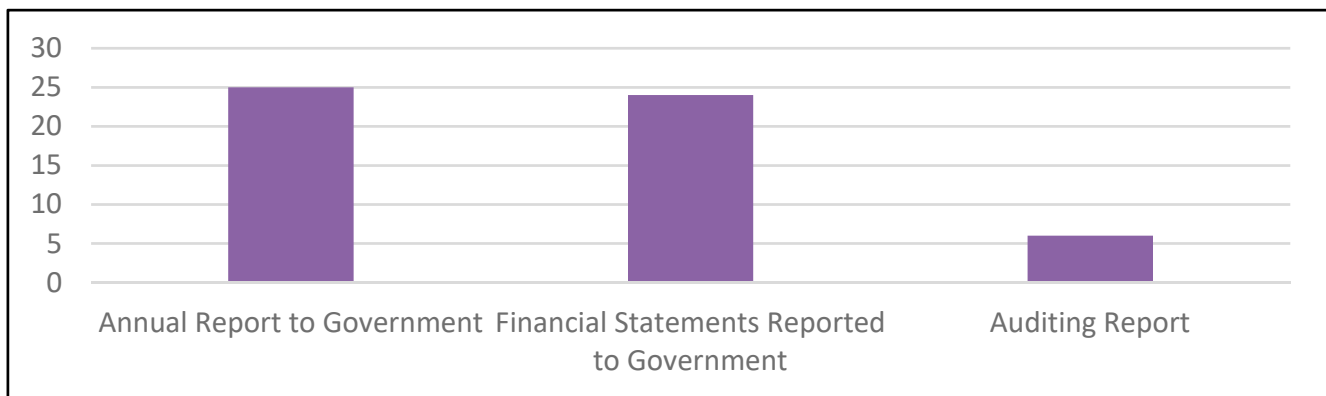

Source: IMF Staff.

\section{Central Bank Internal Accountability}

8. Central banks are not very transparent about ethics or codes of conduct requirements. Most central banks are not transparent about whether they have an ethics committee (or other type of ethical oversight) in the central bank. Similarly, most central banks are not transparent about the possible existence of a code of conduct for Board members and/or for central bank staff. (Figure 7).

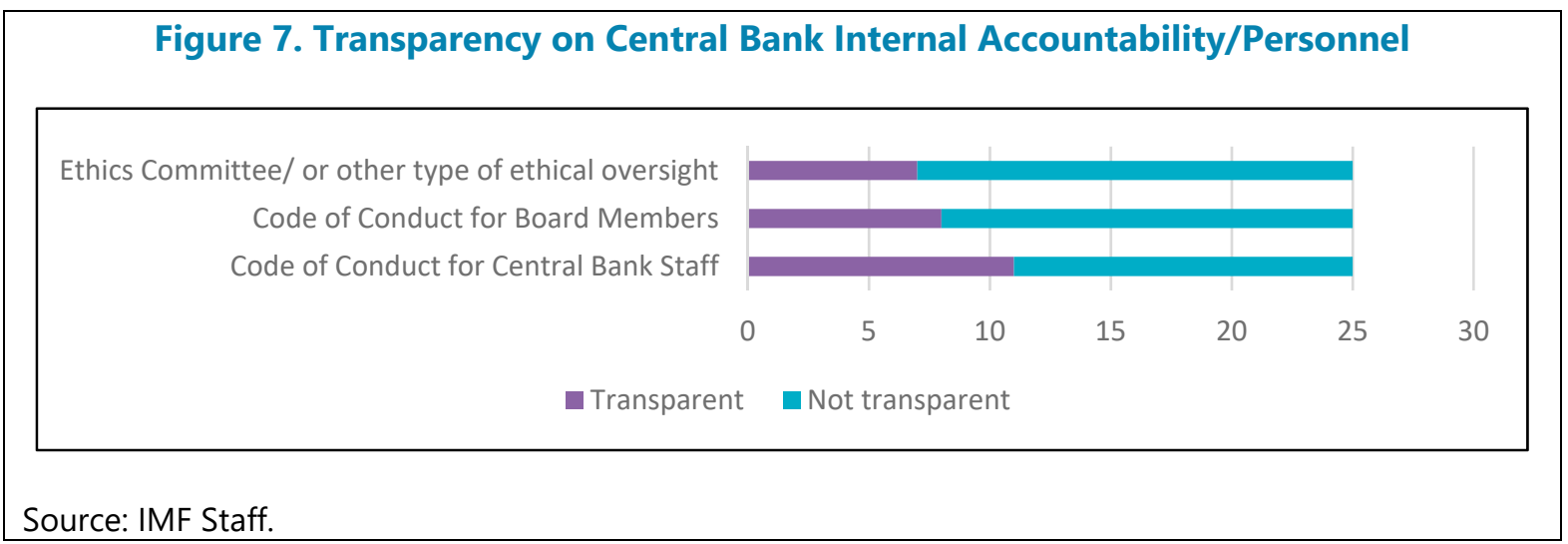

\section{Central Bank Risk Management}

9. One-third of central banks is not transparent about their internal risk management. Transparency on central bank risk management (Figure 8) is divided in two categories: (1) risk appetite, risk policies, and risk framework, and (2) risk management decision-making structure. In both cases, one-third of central banks is not transparent about whether these exist within the central 
bank. In two cases, the central banks indicated neither categories are applicable-this is somewhat odd, as most central banks have some form of risk management, advanced or nascent.

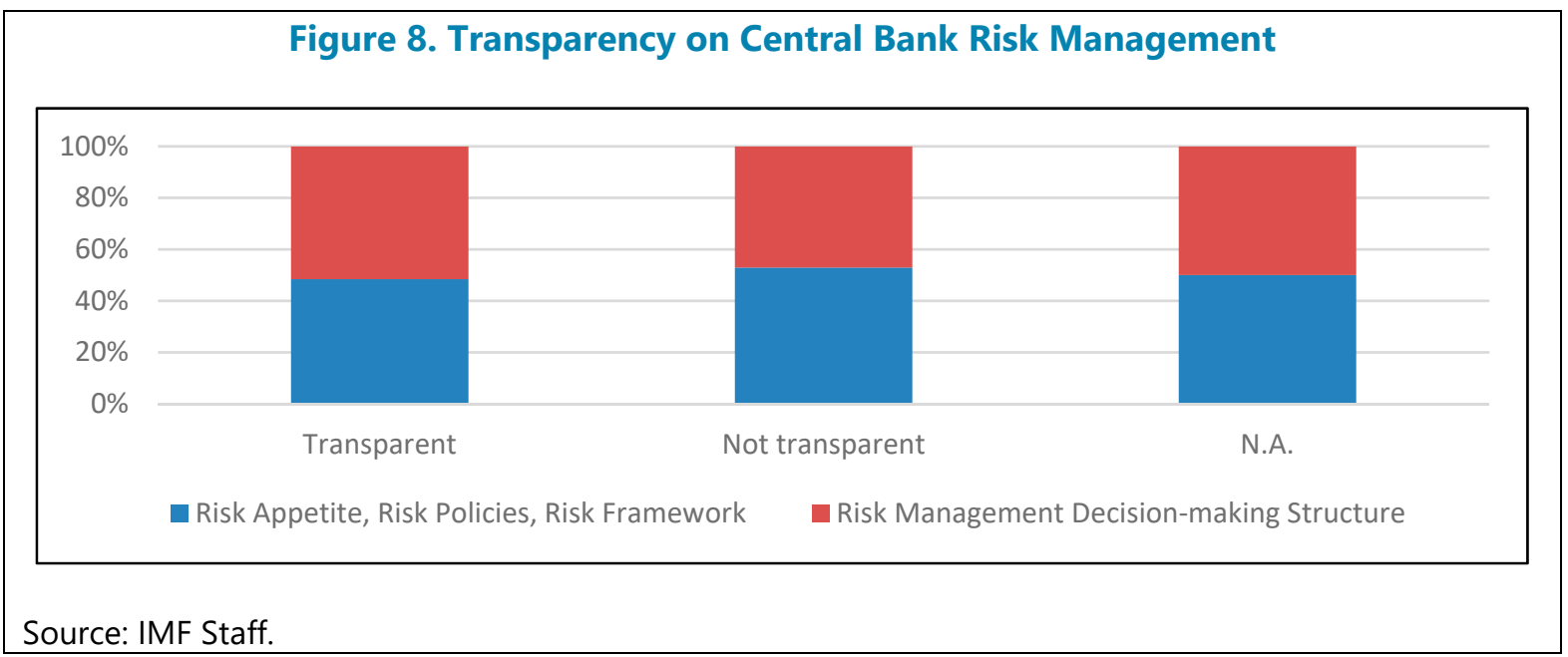

\section{Central Bank Communication Strategy and Policy}

\section{Almost all central banks are transparent about their institutional communication}

arrangements. Except for two central banks, all have published information on their institutional communication arrangements. This also holds for most central banks when it comes to transparency on the existence of policies or legal obligations to inform the public (Figure 9). As far as possible publication or reporting enhancements go, less than half of the central banks are transparent on whether they have undergone such enhancements.

Figure 9. Central Bank Transparency on Communication

Publishing / reporting enhancement (date, if possible) Central bank policies or legal obligation to inform the public

Institutional communications arrangement

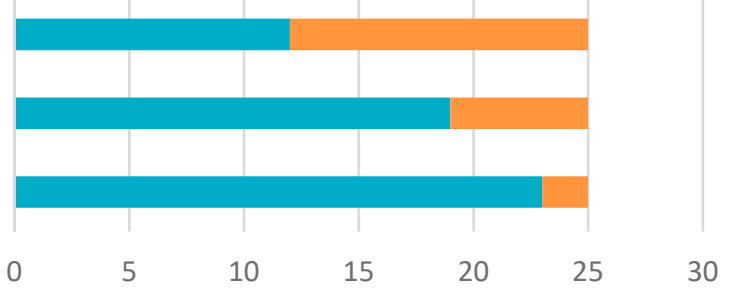

- Transparent Not transparent $\quad$ N.A.

Source: IMF Staff. 


\section{Central Bank Secrecy and Confidentiality}

\section{Almost all central banks are transparent about general secrecy and confidentiality} rules for central bank staff. With two exceptions, most central banks indicate that they have general secrecy and confidentiality rules established in the central bank law, and that these general rules are applicable for central bank staff. Central banks are less transparent about whether specific rules for Board members' secrecy and confidentiality arrangements are established in the central bank, with about 60 percent being transparent about whether such arrangements exist. As far as specific financial stability-related rules go, less than half of central banks are transparent about whether the central bank law has arrangements. In the cases of five central banks, these arrangements are not applicable (Figure 10).

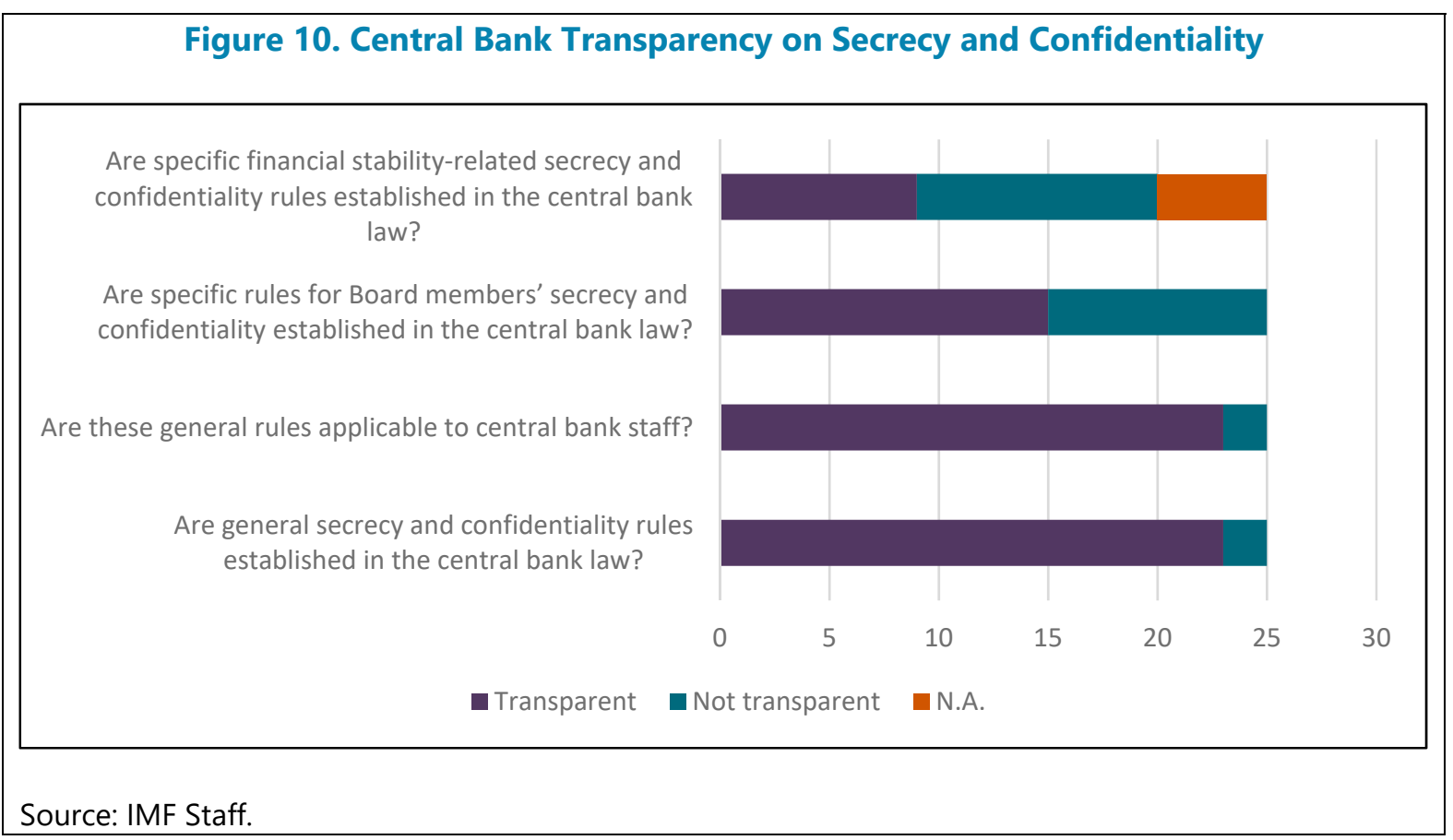

\section{Pillar II. Transparency in Policies}

12. Near to all central banks are transparent about policy. All central banks are transparent about their policies relating to payment system policy, monetary policy, and macroprudential oversight. In many cases the central bank is transparent about it not having a mandate on policy areas relating to financial integrity, consumer protection, macro-prudential oversight, microprudential supervision, and resolution. Transparency is lacking predominantly on financial integrity policy (in those cases where this is part of the central bank's mandate), and to a lesser extent on ELA, consumer protection, and microprudential (Figure 11). 


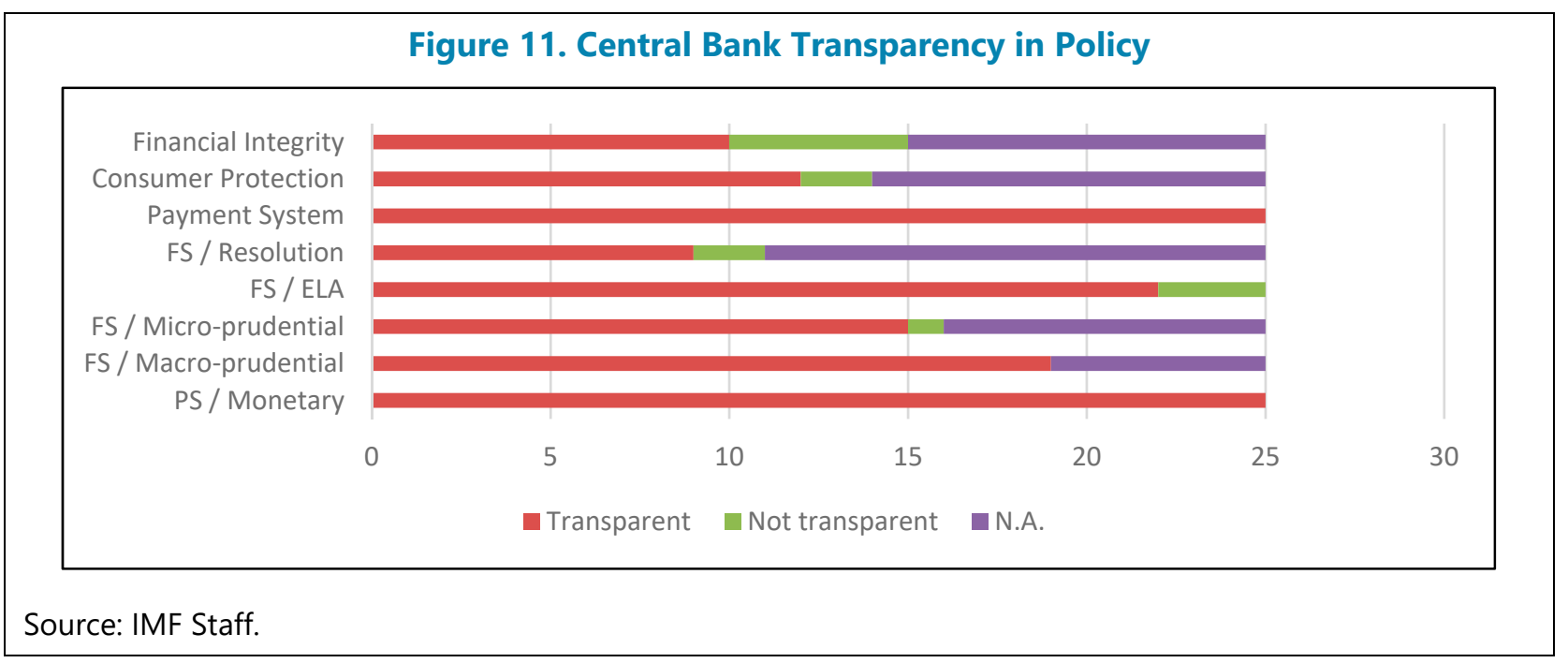

\section{Pillar III. Transparency in Operations}

\section{All central banks are transparent about monetary and payment systems operations,} with lacking transparency in all other areas. Central banks lack transparency in particular on operations relating to ELA, financial integrity, and consumer protection, and to a lesser extent on macroprudential and microprudential, as well as resolution, financial integrity, and consumer protection seem to be areas where central bank operations are not always transparent. In part this could be related to the lack of an explicit mandate (see above). Similarly, for ELA, there is also a large number of central banks that are not transparent on their operations. As noted above, this could be related to the perceived need for certain ambiguity on ELA (mandate, policy, and operations) to avoid moral hazard (Figure 12).

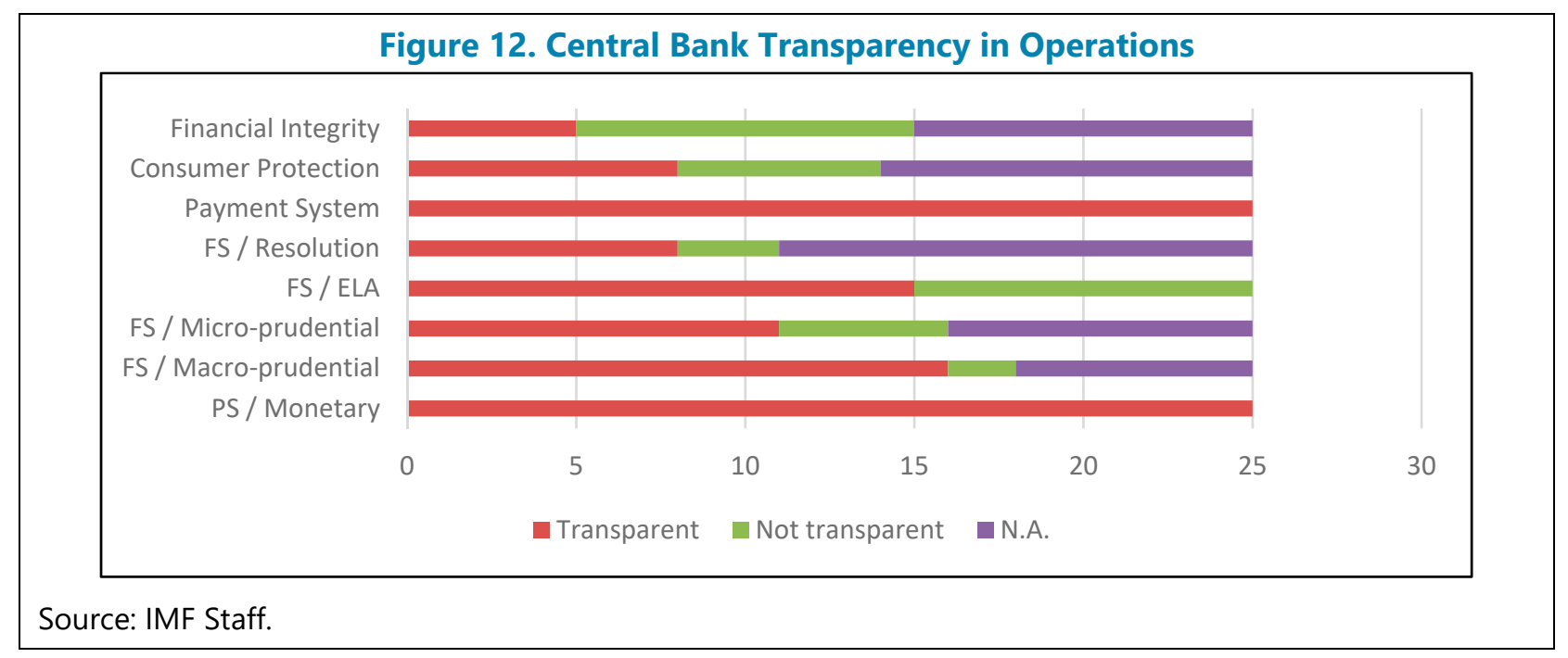




\section{Pillar IV. Transparency in Outcome}

\section{Central banks are mostly transparent about the outcomes of their policies and} operations price stability. For price stability outcomes, this transparency holds for reporting to parliament and to the minister. However, regarding target, operations, and activities relating to price stability, half of all central banks are not transparent. Similar large transparency gaps occur in reporting to parliament on outcomes of consumer protection and financial integrity for almost all central banks that have these objectives (see mandate above). Similarly, more than half of the central banks does not report to parliament on outcomes of their payments system objective. The same holds for a couple of financial stability cases (Figure 13).

Figure 13. Central Bank Transparency in Outcome

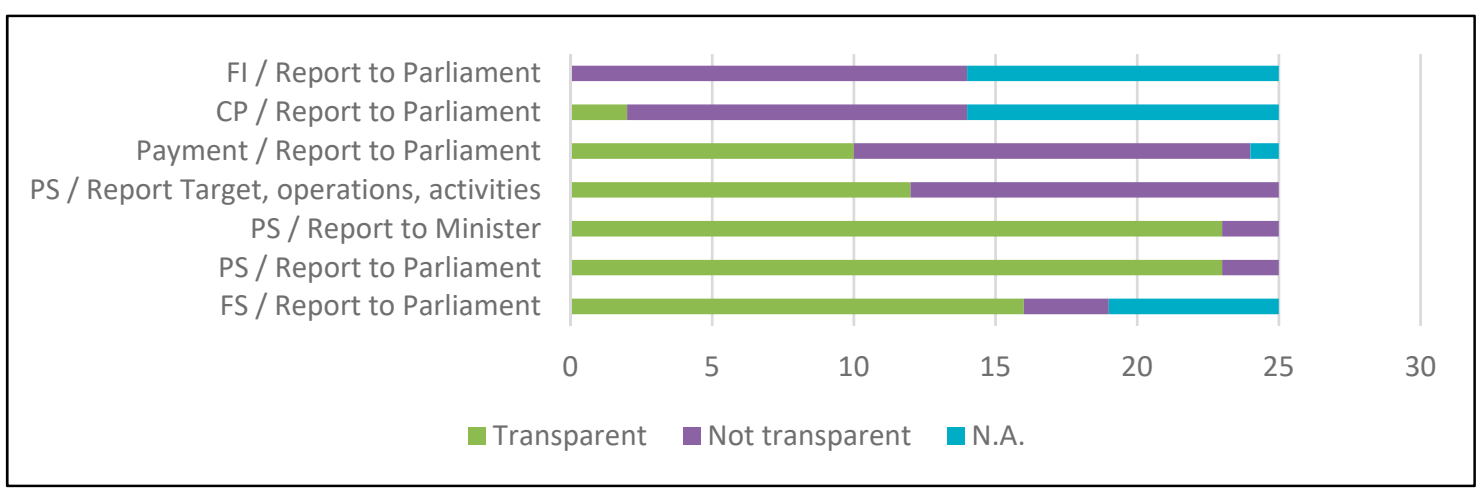

Source: IMF Staff.

\section{Pillar V. Transparency in Official Relations}

\section{Central banks are mostly transparent about relationships with the government, with} the notable exception of the credit function. This transparency holds for the cashier, depository, and agency functions of the central bank. Transparency on the credit function of the central bank to government is lacking in more than half of the country cases. This could relate to the sensitivity of the central bank providing direct or indirect credit to government, and therefore providing fiscal financing - which could be at odds with the central bank's explicit legal mandate (Figure 14). In several cases, the central bank is also not transparent about its consultation with government. 
Figure 14. Central Bank Transparency in Relationships with the Government

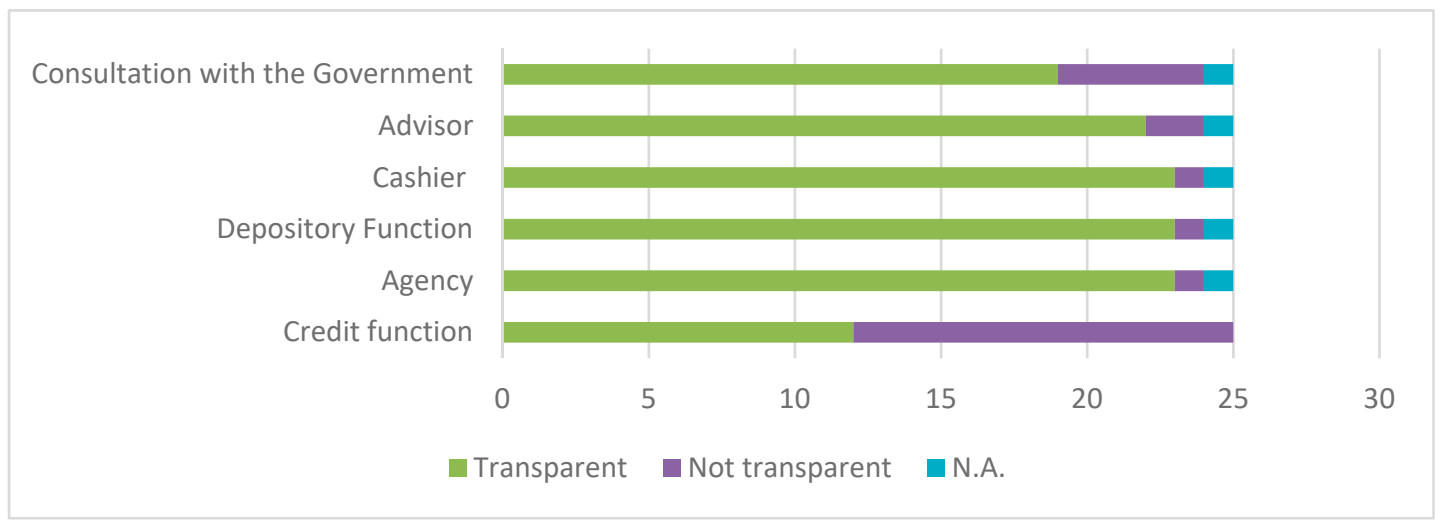

Source: IMF Staff. 


\section{Annex III. Central Bank Transparency Code and Transparency of Financial Policies}

The Central Bank Transparency (CBT) Code will rely on other relevant international standards or principles that contain transparency requirements or recommendations, in as far as these apply to those cases where the central bank is also a financial (banking and/or insurance) supervisor, and/or securities' supervisor, and/or financial market infrastructure.

\begin{tabular}{|c|c|c|c|c|}
\hline \# & Title & Issued by & Examples of Transparency Requirements & CBT Equivalent \\
\hline 1 & $\begin{array}{l}\text { Core Principles for } \\
\text { Effective Banking } \\
\text { Supervision: } \\
\text { - Core Principle 1: } \\
\text { Responsibilities, } \\
\text { Objectives and } \\
\text { Powers } \\
\text { - Core Principle 2: } \\
\text { Independence, } \\
\text { accountability, } \\
\text { resourcing and } \\
\text { legal protection } \\
\text { for supervisors }\end{array}$ & BCBS & $\begin{array}{l}\text { Essential criteria: } \\
\text { 1. "The operational independence, } \\
\text { accountability and governance of the } \\
\text { supervisor are prescribed in legislation } \\
\text { and publicly disclosed" } \\
\text { 2. "The process for the appointment and } \\
\text { removal of the head(s) of the } \\
\text { supervisory authority and members of } \\
\text { its governing body is transparent" } \\
\text { 3. "The supervisor publishes its objectives } \\
\text { and is accountable through a } \\
\text { transparent framework for the discharge } \\
\text { of its duties in relation to those } \\
\text { objectives" } \\
\text { 4. "The supervisor has effective internal } \\
\text { governance and communication } \\
\text { processes... The governing body is } \\
\text { structured to avoid any real or perceived } \\
\text { conflicts of interest" }\end{array}$ & $\begin{array}{l}\text { Pillar I (e.g., mandate, } \\
\text { autonomy, decision-making } \\
\text { structures, communication, } \\
\text { codes of conduct/conflicts } \\
\text { of interest, legal protection). } \\
\text { Pillar IV (outcome) }\end{array}$ \\
\hline 2 & $\begin{array}{l}\text { Insurance Core } \\
\text { Principles: } \\
\text { - } \quad \text { Core Principle 1: } \\
\text { Objectives, } \\
\text { Powers and } \\
\text { Responsibilities } \\
\text { of the Supervisor } \\
\text { - Core Principle 2: } \\
\quad \text { Supervisor }\end{array}$ & IAIS & $\begin{array}{l}\text { 1.1 "Primary legislation clearly defines the } \\
\text { authority (or authorities) responsible for } \\
\text { insurance supervision" } \\
\text { 1.2 "Primary legislation clearly defines the } \\
\text { objectives of insurance supervision and } \\
\text { the mandate and responsibilities of the } \\
\text { supervisor..." } \\
2.1 \text { "The governance structure of the } \\
\text { supervisor is clearly defined. Internal } \\
\text { governance procedures, including } \\
\text { internal audit arrangements, are in place } \\
\text { to ensure the integrity of supervisory } \\
\text { actions. There is effective } \\
\text { communication..." } \\
\text { 2.2 "There are explicit procedures regarding } \\
\text { the appointment and dismissal of the } \\
\text { head of the supervisor and members of } \\
\text { its governing body... When the head of } \\
\text { the supervisor or members of its }\end{array}$ & $\begin{array}{l}\text { Pillar I (e.g., mandate, } \\
\text { autonomy, decision-making } \\
\text { structures, communication, } \\
\text { codes of conduct / conflicts } \\
\text { of interest, legal protection). } \\
\text { Pillar IV (outcome) } \\
\text { Pillar V (Official Relations) }\end{array}$ \\
\hline
\end{tabular}




\begin{tabular}{|c|c|c|c|c|}
\hline & & & $\begin{array}{l}\text { governing body are removed from } \\
\text { office, the reasons are publicly } \\
\text { disclosed" } \\
\text { 2.3 "The institutional relationships between } \\
\text { the supervisor and the executive and } \\
\text { judicial authorities are clearly defined } \\
\text { and transparent..." } \\
\text { 2.4 "The supervisor and its staff are free } \\
\text { from undue political, governmental and } \\
\text { industry interference in the performance } \\
\text { of supervisory responsibilities..." } \\
\text { 2.5 "There are clear and transparent } \\
\text { regulatory requirements and } \\
\text { supervisory procedures which are } \\
\text { appropriate for the objectives that they } \\
\text { are intended to meet... These regulatory } \\
\text { requirements and supervisory } \\
\text { procedures are published" } \\
\text { "The supervisor publishes information } \\
\text { on the insurance sector, about its own } \\
\text { role and how it performs its duties" }\end{array}$ & \\
\hline 3 & $\begin{array}{l}\text { Objectives and } \\
\text { Principles of } \\
\text { Securities } \\
\text { Regulation: } \\
\text { - A. Principles } \\
\text { Relating to the } \\
\text { Regulator }\end{array}$ & IOSCO & $\begin{array}{l}\text { 1. "The responsibilities of the Regulator } \\
\text { should be clear and objectively stated. } \\
\text { 2. The Regulator should be operationally } \\
\text { independent and accountable in the } \\
\text { exercise of its functions and powers. } \\
\text { 3. The Regulator should have adequate } \\
\text { powers, proper resources and the } \\
\text { capacity to perform its functions and } \\
\text { exercise its powers. } \\
\text { 4. The Regulator should adopt clear and } \\
\text { consistent regulatory processes. } \\
\text { 5. The staff of the Regulator should } \\
\text { observe the highest professional } \\
\text { standards, including appropriate } \\
\text { standards of confidentiality. } \\
\text { 6. The Regulator should have or contribute } \\
\text { to a process to identify, monitor, } \\
\text { mitigate and manage systemic risk, } \\
\text { appropriate to its mandate. } \\
\text { 7. The Regulator should have or contribute } \\
\text { to a process to review the perimeter of } \\
\text { regulation regularly. } \\
\text { 8. The Regulator should seek to ensure } \\
\text { that conflicts of interest and } \\
\text { misalignment of incentives are avoided, } \\
\text { eliminated, disclosed or otherwise } \\
\text { managed." }\end{array}$ & $\begin{array}{l}\text { Pillar I (e.g., mandate, } \\
\text { autonomy, decision-making } \\
\text { structures, communication, } \\
\text { codes of conduct/conflicts } \\
\text { of interest, legal protection). }\end{array}$ \\
\hline
\end{tabular}




\begin{tabular}{|c|c|c|c|c|}
\hline 4 & $\begin{array}{ll}\text { Principles for } \\
\text { Financial Market } \\
\text { Infrastructures: } \\
\text { - } \quad \text { Principle } 1 \\
\quad \text { (Legal Basis) } \\
\text { - } \quad \text { Principle } 2 \\
\quad \text { (Governance) } \\
\text { - } \quad \text { Principle 22 } \\
\quad \text { (Communication } \\
\text { procedures and } \\
\text { standards) } \\
\text { Principle 23 } \\
\text { (Disclosure of } \\
\text { rules, key } \\
\text { procedures, and } \\
\text { market data) }\end{array}$ & $\begin{array}{l}\text { CPMI- } \\
\text { IOSCO }\end{array}$ & $\begin{array}{l}\text { 1. An FMI should have a well-founded, clear, } \\
\text { transparent, and enforceable legal basis } \\
\text { for each material aspect of its activities } \\
\text { in all relevant jurisdictions. } \\
\text { 2. An FMI should have governance } \\
\text { arrangements that are clear and } \\
\text { transparent, promote the safety and } \\
\text { efficiency of the FMI, and support the } \\
\text { stability of the broader financial system, } \\
\text { other relevant public interest } \\
\text { considerations, and the objectives of } \\
\text { relevant stakeholders. } \\
\text { 22. An FMI should use, or at a minimum } \\
\text { accommodate, relevant internationally } \\
\text { accepted communication procedures } \\
\text { and standards in order to facilitate } \\
\text { efficient payment, clearing, settlement, } \\
\text { and recording. } \\
\text { 23. An FMI should have clear and } \\
\text { comprehensive rules and procedures } \\
\text { and should provide sufficient } \\
\text { information to enable participants to } \\
\text { have an accurate understanding of the } \\
\text { risks, fees, and other material costs they } \\
\text { incur by participating in the FMI. All } \\
\text { relevant rules and key procedures should } \\
\text { be publicly disclosed. }\end{array}$ & $\begin{array}{l}\text { Pillar I (e.g., mandate, } \\
\text { autonomy, decision-making } \\
\text { structures, communication, } \\
\text { codes of conduct/conflicts } \\
\text { of interest, legal protection). }\end{array}$ \\
\hline
\end{tabular}




\section{Bibliography}

Ambtenbrink, F., 2004, The Three Pillars of Central Bank Governance - Towards a Model Central Bank Law or a Code of Good Governance?, article based on presentations during an IMF LEG Workshop in Central Bank, March 2004.

Arnone, M., B. J. Laurens, e.a., 2006, The Measurement of Central Bank Autonomy: Survey of Models, Indicators, and Empirical Evidence, IMF Working Paper 06/227.

Berger, H., V. Nitsch, e.a., 2006, Central Bank Boards Around the World: Why Does Membership Size Differ, IMF Working Paper 06/281.

Blinder, A., Ehrmann, M, e.a., 2017, Necessity as the mother of invention: monetary policy after the crisis, Economics Policy October 2017, pp. 707-755.

Blinder, A.S., C. Goodhart., e.a., 2001, How do Central Banks Talk, International Center for Monetary and Banking Studies,

Bossu, W., S. Hagan, e.a., 2017, Safeguarding Central Bank Autonomy: The Role of Transparency and Accountability, ECB Legal Conference 2017 (Shaping a new legal order for Europe: a tale of crises and opportunities, 4-5 September 2017).

Crowe, C., E.E. Meade, 2008, Central Bank Independence and Transparency: Evolution and Effectiveness, IMF Working Paper 08/119.

Cukierman, A., S.B. Webb, e.a., 1992, Measuring the Independence of Central Banks and Its Effect on Policy Outcomes, The World Bank Economic Review, Vol. 6, No. 3, pp. 353-398.

De Haan, J., S.C.W. Eijffinger, e.a., 2007, Central bank transparency and central bank communication: Editorial introduction, European Journal of Political Economy 23 (2007), pp. 1-8.

FSB, 2013, Principles for An Effective Risk Appetite Framework. Basel: Bank for International Settlements.

FSB, 2014, Key Attributes of Effective Resolution Regimes for Financial Institutions. Basel: Bank for International Settlements.

Garriga, A.C., 2016, Central Bank Independence in the World: A New Data Set, International Interactions, 2016, Vol. 42, No. 5, pp. 849-868. 
Goodhart, C., D. Schoenmaker, 1995, Should the Functions of Monetary Policy and Banking

Supervision Be Separated?, Oxford Economic Papers, New Series, Vol. 47, No. 4 (Oct., 1995), pp. 539560.

Hoffmann-Axthelm, L. (ed.), 2017, Two Side of the Same Coin? Independence and Accountability of the European Central Bank, Transparency International EU.

Issing, O., 2005, Communication, Transparency, Accountability: Monetary Policy in the Twenty-First Century, Federal Reserve Bank of St. Louis Review, March/April 2005, 87 (2, Part 1), pp. 65-83.

Jeanneau, S., 2011, Central bank governance and financial stability: issues of potential relevance to Africa, BIS Papers, No. 56, Sept. 2011.

Khan, A., 2016, Central Bank Governance and the Role of Nonfinancial Risk Management, IMF Working Paper 16/34. Washington: International Monetary Fund.

Khan, A., 2018, Legal Protection: Liability and Immunity Arrangements of Central Banks and Financial Supervisors, IMF Working Paper 18/176. Washington: International Monetary Fund.

Koetter, M., K. Roszbach, e.a., 2014, Financial Stability and Central Bank Governance, International Journal of Central Banking, December 2014.

Lefort, D., 2006, Transparency and accountability of central banks, as retrieved from www.cemla.org/legales/docs/leg-06-lefort.pdf.

Lybek, T., J. Morris, 2004, Central Bank Governance: A Survey of Boards and Management, IMF Working Paper 04/226.

Masciandaro, D., D. Romelli, 2015, Ups and downs of central bank independence from the Great Inflation to the Great Recession: theory, institutions and empirics, Financial History Review, December 2015, pp. 1-31.

McCallum, B.T., 1995, Two Fallacies Concerning Central Bank Independence, NBER Working Paper, No, 5075, March 1995.

Posen, A.S., 1995, Declarations Are Not Enough: Financial Sector Sources of Central Bank Independence, NBER Macroeconomics Annual, Vol. 10 (1995), pp. 253-274.

Romelli, D., 2017, The political economy of reforms in central bank design: evidence from a new dataset, BAFFI CAREFIN Centre Research Paper No. 2018-87. 
Romelli, D., 2018, Regulatory reforms and central bank independence, Financial History Review, Cambridge University Press, vol. 22(03), pp. 259-289, December 2015, BAFFI CAREFIN Centre Research Paper No. 2015-3.

Svensson, L. E. O., 2015, Monetary Policy and Macroprudential Policy: Different and Separate, Conference draft to be presented at "Macroprudential Monetary Policy," October 2-3, 2015. 